Isoprenoid emission in hygrophyte and xerophyte European woody flora: ecological and evolutionary implications

${ }^{1}$ Consiglio Nazionale delle Ricerche, Dipartimento di Scienze Bio-Agroalimentari, Piazzale Aldo Moro 7, 00185 Roma, Italia; ${ }^{2}$ Consiglio Nazionale delle Ricerche, Istituto per la Protezione delle Piante, Via Madonna del Piano 10, 50019 Sesto Fiorentino (Firenze), Italia; ${ }^{3}$ Consiglio Nazionale delle Ricerche, Istituto di Biologia Agroambientale e Forestale, Via Marconi 3, Porano (Terni), Italia; ${ }^{4}$ Università degli Studi di Napoli 'Federico II, Dipartimento di Biologia, Complesso Universitario di Monte S. Angelo, Via Cinthia, 80126 Napoli, Italia; ${ }^{5}$ Università degli Studi della Tuscia, Dipartimento di Scienze e Tecnologie per l'Agricoltura, le Foreste, la Natura e l'Energia, Via San Camillo de Lellis, 01100 Viterbo, Italia; ${ }^{6}$ Università degli Studi della Tuscia, Dipartimento per 1' Innovazione nei sistemi Biologici, Agroalimentari e Forestali, Via San Camillo de Lellis, 01100 Viterbo, Italia; ${ }^{7}$ MTA-ELTE-MTM Ecology Research Group, H-1117 Budapest, Pázmány Péter sétány 1/C, Hungary; ${ }^{8}$ MTA-DE "Lendület" Behavioural Ecology Research Group, University of Debrecen, H-4032 Debrecen, Egyetem tér 1, Hungary; ${ }^{9}$ Università degli Studi Roma 'La Sapienza', Dipartimento di Biologia Ambientale, Piazzale Aldo Moro 500185 Roma, Italia.

${ }^{*}$ Correspondence: Francesco Loreto, CNR- Dipartimento di Scienze Bio-Agroalimentari, Piazzale Aldo Moro 7, 00185

Roma, Italia. Email: francesco.loreto@enr.it

Type of article: Research paper

Running title: Isoprenoid emission in hygrophytes and xerophytes 
ABSTRACT

31

Aim. The relationship between isoprenoid emission and hygrophily was investigated in woody plants of the Italian flora, which is representative of European diversity.

Methods. Volatile isoprenoids (isoprene and monoterpenes) were measured or data collected from the literature, on 154 species native or endemic in the Mediterranean. The Ellenberg indicator value for moisture (EIVM) was used to describe plant hygrophily. Phylogenetic analysis was carried out, at a broader taxonomic scale on 128 species, and then refined on strong isoprene emitters (Salix and Populus species) based on isoprene synthase gene sequences (IspS).

Results. Isoprene emitters were significantly more common, and isoprene emission was higher in hygrophilous EIVM classes, whereas monoterpene emitters were more widespread, and monoterpene emission was higher, in xeric classes. However, when controlling for phylogeny, isoprene emission was not associated with EIVM, possibly due to the large presence of Salicaceae among hygrophilous isoprene emitters. Moreover, the distribution of isoprene emitters among EIVM classes was not related to IspS-based phylogenesis in Populus and Salix, suggesting that the gene has not undergone evolution linked to ecological pressure. In contrast, monoterpene emission pattern is independent of phylogeny, suggesting that the evolution of monoterpenes is associated

50 with transitions to more xeric habitats.

Main conclusions. Our results reveal an interesting ecological pattern linking isoprenoids and water availability. The idea is surmised that isoprene is a trait that i) evolved in plants adapted to high water availability; ii) is replaced by more effective protection mechanisms, e.g. more stable isoprenoids, in plants adapting to more xeric environments; iii) being strongly constrained by phylogeny, persists in Salicaceae adapted to more xeric environments.

Keywords: Adaptation, Chemo-taxonomy, Hygrophytes, Isoprene, Monoterpenes, Phylogenies,

Salicaceae, Xerophytes, Water stress. 


\section{INTRODUCTION}

65

Leaves of many woody and perennial plants constitutively emit volatile isoprenoids (isoprene and monoterpenes) to the atmosphere, at rates that often exceed 1-2\% of the photosynthetic carbon fixation, especially in stressed leaves (Loreto \& Schnitzler 2010). Isoprene and monoterpenes are formed from photosynthetic metabolism in the chloroplasts (Loreto \& Schnitzler 2010). Generally, either isoprene or monoterpenes are emitted but not both (Harrison et al. 2013). However, some species (e.g. Myrtales) show significant storage of monoterpenes in specialized structures and these species can emit both isoprene and monoterpenes (Niinemets et al. 2004). Isoprene is believed to play a role against thermal and oxidative stresses, possibly because of the capacity of this molecule to stabilize thylakoidal membranes (Singsaas et al. 1997, Velikova et al. 2011), or to remove reactive oxygen or nitrogen species within the mesophyll (Loreto \& Velikova 2001; Vickers et al. 2009). Light-dependent monoterpenes may play similar roles, but they are also often involved in plant communication with other organisms, especially in multitrophic plant defense and pollination (Dicke \& Baldwin 2010).

The emission of isoprene and monoterpenes is widespread across plant families (Harley et al. 1999). A recent study has indicated a strong phylogeographic signal for monoterpenes; the emission of monoterpenes is qualitatively different in cork oaks across their distribution range in Europe (Loreto et al. 2009). Alien species of Hawaii emit more monoterpenes than native ones, which is also suggested to be an indication of greater evolutionary success of alien species since monoterpene emission is associated with higher stress resistance (Llusiá et al. 2010).

However, there seems to be no straightforward relationship between isoprene emission and plant taxonomy or phylogeny. Isoprene emission is absent in herbaceous, annual vegetation, whereas it is widespread in trees and perennial plants (Kesselmeier and Staudt 1999). However, this robust trend may not be associated to phylogeny, as isoprene emission is limited to woody life-forms of families that also include herbaceous species (Fineschi et al. 2013). Hanson et al. (1999) reported that isoprene emission is more widespread in mosses than in all other taxa, and this is so far the only unambiguous phylogenetic pattern. This finding led to the suggestion that the isoprene emission trait evolved when plants conquered the land and started coping with more severe thermal extremes than in the water-buffered environment (Hanson et al. 1999). Similarly, Vickers et al. (2009) and Fineschi \& Loreto (2012) commented that isoprene could have evolved as a first mechanism to cope with more recurrent and stronger oxidative stress in the terrestrial than in aquatic environments, being then replaced by more effective mechanisms when plants adapted to more 
97 xeric conditions. No other adaptive relationships are apparent when dealing with volatile 98 isoprenoids emitted from plants that do not have specialized structures to accumulate isoprenoids.

99 We reasoned that, if the emission of isoprene has evolved in plants conquering the land, then the 100 trait could still be more widespread in hygrophytes than in xerophytes. To test this idea, the 101 emission of isoprene was assessed in the Italian woody flora, which is representative of the 102 Mediterranean eco-region, one of the primary global biodiversity hotspots, and an area of 103 exceptional biodiversity value exhibiting high endemism (Blondel \& Aronson 1999; Médail \& 104 Quézel 1999; Comes 2004; Thompson 2005; Médail \& Diadema 2009). Further, the vast majority 105 of the tree genera of continental and northern-Europe (including Scandinavia and the British Isles) 106 naturally occurs in Italy today, as the Italian peninsula was one of the main Quaternary glacial 107 refugia (Bennet et al. 1991). Thus, the Italian woody species account for most of the total European 108 diversity of trees and shrubs.

109 The Ellenberg indicator values (EIV; Ellenberg 1974; Ellenberg et al. 1991) characterize the 110 adaptation of a vascular plant species to edaphic and climatic conditions in comparison to other 111 species: i.e., each plant species is given values denoting the position at which plants reach peak 112 abundance along environmental gradients (Diekmann 2003; Godefroid \& Dana 2007). A 9- or 12113 point ordinal scale for each of the following parameters is used: moisture, soil nitrogen status, soil $114 \mathrm{pH}$, soil chloride concentration, light, temperature and continentality. Although EIV were originally 115 designed for Central Europe and assigned to the Central European flora only (Ellenberg 1974; 116 Ellenberg et al. 1991), they have been subsequently redefined and calculated for other floras, such 117 as Britain (Hill et al. 1999), Southern Greece (Böhling et al. 2002) and Italy (Pignatti et al. 2005). 118 EIV have been widely used to interpret responses to environmental gradients (Diekmann 2003), and 119 are now used also as an effective tool for applied purposes, such as remotely-sensed vegetation 120 monitoring (Schmidtlein 2005), conservation strategies (Sullivan et al. 2010), ecological restoration 121 (Krecek et al. 2010), and prediction of pollution effects (Jones et al. 2007 ; Dupré et al. 2010).

122 Experimental studies found that EIV ranking within a given flora is a highly reliable indicator of 123 adaptation to environmental conditions (Schaffers \& Sýcora 2000; Diekmann 2003; Schmidtlein 124 2005; Jones et al. 2007; Klaus et al. 2012): in particular, the index for soil moisture (EIVM) was 125 found to perform the best (Schaffers \& Sýcora 2000; Fanelli et al. 2007; Krecek et al. 2010). The 126 EIVM was therefore used here to rank isoprenoid-emitting species of the Italian woody flora 127 according to an index of hygrophily.

128 Two phylogenetic analyses were carried out on this dataset at different taxonomic scales. The first 129 analysis was performed at a broad scale on woody species belonging to 31 different orders 130 representing main lineages among woody plant species, to assess whether isoprenoids emissions 
131 and EIVM show phylogenetic signal (i.e. whether phylogenetically related species tend to have 132 more similar EIVM and/or isoprenoid emission values than more distantly related species). The 133 second analysis was performed on a narrower range of taxa to assess whether changes of the coding 134 sequences of isoprene synthase (IspS), the enzyme responsible for isoprene production (Silver \& 135 Fall 1995; Loreto \& Schnitzler 2010), are associated with changes of EIVM. To perform the latter 136 test, poplars (Populus sp.) and willows (Salix sp.), two main genera of isoprene emitters in the 137 Mediterranean area and worldwide (Kesselmeier \& Staudt 1999), with plant species spanning 138 several classes of EIVM, were studied in detail.

139 140 141 142 143 144 145 146 147 148 149 150 151 152 153 154 155 156 157 158 159

160 161 162 163 164

\section{MATERIALS AND METHODS}

\section{Plant material}

Constitutive emissions of isoprene and monoterpenes from light-dependent pools that are not concentrated in storage compartments, are found almost exclusively in perennial, woody plants (Loreto \& Schnitzler 2010), thus this survey was limited to these plant species. A check-list of woody species (i.e., trees, shrubs and lignified lianas) of the flora of Italy, was compiled using, as a first approximation, the life form assignments made by Pignatti (1982). This preliminary list, only including Phanerophytes (P) and Nano-phanerophytes (NP) life forms, was then complemented with some Chamaephyte (Ch) species that, based on field experience and on species description in regional floras, are in fact lignified shrubs. Further refinement was done by deleting from the checklist: i) all non-native species, as Ellenberg indices can be defined only in comparison to other species growing in natural communities within an homogeneous biogeographical area. Exceptions were possible for those species of very ancient or controversial introduction, such as Castanea sativa and Pinus pinea, or for alien plants that are now widely naturalized in the Mediterranean vegetation (e.g. Robinia pseudoacacia); ii) the micro-species of critical genera such as Rosa and Rubus (which were then limited to 'main' species; cf. Diekmann 2003); iii) the hybrid taxa and the species of controversial taxonomic value [i.e., those species listed in Pignatti (1982), but rejected or doubtfully accepted in Conti et al. 2005]; iv) some species which had an obviously wrong life form in Pignatti (1982). As a result, 323 plant species were considered in the check-list of the Italian woody flora (Appendix S1).

\section{The Ellenberg ecological indicator for moisture}


165 We used the Ellenberg indicator value for moisture (EIVM) to formalize the ranking of the woody 166 species along a gradient of hygrophily. The ordinal scale defined by Ellenberg (1974) for EIVM is 167 composed of 12 classes; however no woody species of the Italian flora fall within classes 10-12 (i.e. 168 plants with permanently submerged roots and aquatic plants, see Pignatti et al. (2005)). Thus, the 169 EIVM of the species included in the present work range from class 1 (plants of extremely arid habitats), to class 9 (species of marshy soils undergoing frequent root submersion).

171 The EIVM were assigned to plants according to Pignatti et al. (2005). However, for 39 species the 172 original attribution by Pignatti et al. (2005) was either considered obviously wrong (see Fanelli et 173 al. 2007), or missing. In these cases the correct EIVM was attributed according to descriptive 174 vegetation papers and original field data, as recorded during field surveys to collect volatile 175 isoprenoids (Appendix S1).

176

177

178

179

180

181

182

183

184

185

186

187

188

189

190

191

192

193

194

195

196

197

198

\section{Volatile isoprenoids}

The emission of volatile isoprenoids was reported for 149 species, i.e. about half of the total native woody flora of Italy, and in five exotic species common in the Mediterranean vegetation, that we had considered, without any relevant bias in terms of EIVM class (Appendix S1). No important European tree species is missing from the emission database, whereas, for a small number of common European shrubs or lianas (i.e. Clematis vitalba, Cornus sanguinea, Crataegus oxyacantha, Euonymus europaeus, Lonicera caprifolium, Rhododendron sp.pl., Viburnum tinus, Vinca sp.pl.) it was not possible to obtain reliable emission data.

Species were assigned to two Boolean (0/1) categories, emitting or non-emitting, based on the potential emission rate threshold of $1 \mu \mathrm{g} \mathrm{g}^{-1} \mathrm{~h}^{-1}$ for isoprene and $0.2 \mu \mathrm{g} \mathrm{g}^{-1} \mathrm{~h}^{-1}$ for monoterpenes, which are known to be emitted 5-10 times less than isoprene. The emission rates actually measured are also presented, to have a quantitative assessment of the relationship between emission and EIVMs.

Plant material was both collected and tested during the summer months (June-August) in a common garden at CNR-Rome, or measurements of isoprenoid emission were made in situ across Italy in periods (June or September) characterized by high temperatures and non-limiting conditions (especially no drought) for the physiology of plants. In all cases, a LI-COR 6400 (LI-COR, Lincoln Nebraska, USA) was used to standardize measurements in its $6 \mathrm{~cm}^{2}$ gas-exchange cuvette. This leaf area was exposed to $1000 \mu \mathrm{mol} \mathrm{m} \mathrm{m}^{-2} \mathrm{~s}^{-1}$ photosynthetic photon flux density, $30^{\circ} \mathrm{C}$, and $50 \%$ relative humidity, under a flux of $0.5 \mathrm{~L} \mathrm{~min}^{-1}$ of air that was passed through a catalytic converter (Parker Hannifin Corp., ChromGas Zero Air Generator 1001) to filter contaminants and other volatile organic compounds. The released isoprenoids were collected into a cartridge packed with adsorbent 
199 (200 mg of Tenax; SRA Instruments, Milan, Italy). Tenax has been used in many past experiments 200 for isoprene measurements. Though unable to retain high isoprene concentrations without 201 undergoing breakthrough, Tenax may reveal concentrations as low as $<1 \mathrm{ppb}$, thus fulfilling the 202 scope of separating non-emitters when loading small volumes of air onto the adsorbent. Two to five 203 L of air were trapped at a flow of $150 \mathrm{ml} \mathrm{min}^{-1}$ in the cartridge that was placed at the outlet of the 204 cuvette. Measurements were made when the physiological parameters of the leaf (photosynthesis, 205 transpiration, stomatal conductance; also monitored by the LI-COR 6400 instrument) were stable, 206 and were repeated on at least three different leaves of different plants. The number of replications 207 was increased in presence of large intraspecific variation of the emission, particularly in the case of 208 low monoterpene emitters.

209 The cartridges were kept refrigerated until desorbed and analyzed with a GC-MS (Agilent 6850; 210 SRA Instruments) using a capillary column (DB-5, Agilent, $30 \mathrm{~m} \times 0.25 \mathrm{~mm}$ inner diameter and $2110.25 \mu \mathrm{m}$ film thickness). The actual emissions were positively quantified filling the cartridges with $2122 \mathrm{~L}$ of air in which $70 \mathrm{ppb}$ of gaseous standards (Rivoira, Milan, Italy) of isoprene or main 213 monoterpenes ( $\alpha$-pinene, $\beta$-pinene, sabinene, myrcene, limonene) were mixed.

\section{Broad-scale phylogenetic analysis}

We created a composite phylogenetic tree representing the relationships among the studied species (Fig. 1). The tree is based on the Angiosperm Phylogeny Website (Stevens, 2001 onwards) and was further refined based on published molecular phylogenies (Appendix S2). In this way, we could determine the phylogenetic position of 128 species. However, as some of these species tolerate a wide range of moisture conditions (see Appendix S1), the phylogenetic analyses involving EIVM were limited to 119 species.

By using the phylogenetic tree in Fig. 1 we performed an Abouheif (1999) test to assess whether isoprenoids emitters and EIVM show phylogenetic signal at this taxonomic scale. To test the association between phylogenetic signal and hygrophily we used the Ellenberg indicator values for moisture. By contrast, for testing for phylogenetic signal in isoprene and monoterpene emission capability, we performed two distinct tests on the Boolean, emitting/non-emitting (0/1) classes of both isoprenoid emission types.

Next, we used the phylogeny to analyze the relationship between Ellenberg indicator values and isoprenoid emission. Therefore, we built Bayesian Phylogenetic Mixed Models using the MCMCglmm R package (Hadfield 2010, R Core Team 2012), with either isoprene (emitter/nonemitter) or monoterpene (emitter/non-emitter) emission as binary dependent variables and EIVM as explanatory variable. The mixed model implemented in MCMCglmm can incorporate the 
233 phylogenetic relationships among species as a random factor, thereby controlling for the non234 independence of data points due to shared ancestry.

\section{Narrow-scale phylogenetic analysis on Salicaceae}

Leaf samples were collected from Salix and Populus species (Appendix S3) and stored at $-80^{\circ} \mathrm{C}$

until DNA extraction. We selected Populus and Salix because i) species of these two genera play an important role in the woody Mediterranean and European flora, ii) all species emit isoprene, and iii) species from both genera represent several EIVM classes, spanning from class 3 (e.g. Salix alpina) or 5 (Populus tremula) to class 8 (e.g. Salix viminalis or Populus nigra).

242 Total DNA was extracted using Invitek Invisorb Spin Plant Mini Kit (Stratec GmbH, Berlin, 243 Germany) according to manufacturer's instructions, from approximately $100 \mathrm{mg}$ of material, 244 ground in the automatic grinding mill MM200 (Retsch GmbH, Haan, Germany). Isoprene synthase gene was amplified using PaIspS-Fw2 and $\mathrm{Pa} I s p S$-Bw3 primers (Fortunati et al. 2008; Appendix 246 S4). Polymerase chain reactions (PCRs) were performed in $100 \mu$ l containing $30 \mathrm{ng}$ of template DNA, 5x PCR reaction buffer (Promega Corporation, Madison, Wisconsin, USA), $0.2 \mathrm{mM}$ of each dNTPs, $0.2 \mu \mathrm{M}$ of each primer, $2.0 \mathrm{mM} \mathrm{MgCl}$, $3.2 \mathrm{U}$ Taq polymerase (GoTaq, Promega). All samples were amplified on a Mastercycler thermal cycler (Eppendorf, Hamburg, Germany), following two touchdown PCR profiles for Populus and Salix species, respectively: 1) 3 min at $95^{\circ} \mathrm{C}, 15$ touchdown cycles of $95^{\circ} \mathrm{C} 30 \mathrm{~s}, 70^{\circ} \mathrm{C} 1^{\prime}\left(-1^{\circ} \mathrm{C} /\right.$ cycle $), 72^{\circ} \mathrm{C} 2^{\prime} ; 20$ cycles of $95^{\circ} \mathrm{C} 30 \mathrm{~s}$, $55^{\circ} \mathrm{C} 1^{\prime}, 72^{\circ} \mathrm{C} 2^{\prime}$ and final extension at $72^{\circ} \mathrm{C} 10 \mathrm{~min}$; 2) $3 \mathrm{~min}$ at $95^{\circ} \mathrm{C}, 15$ touchdown cycles of $95^{\circ} \mathrm{C} 30 \mathrm{~s}, 65^{\circ} \mathrm{C} 1^{\prime}\left(-1^{\circ} \mathrm{C} /\right.$ cycle $), 72^{\circ} \mathrm{C} 2^{\prime} ; 20$ cycles of $95^{\circ} \mathrm{C} 30 \mathrm{~s}, 50^{\circ} \mathrm{C} 1 ', 72^{\circ} \mathrm{C} 2^{\prime}$ and final extension at $72^{\circ} \mathrm{C} 10 \mathrm{~min}$.

PCR products were purified using GFX PCR DNA and Gel Band Purification Kit (GE Healthcare, Uppsala, Sweden), and directly sequenced on an ABI 3130 Avant automated sequencer (Life Technologies Corporation, Carlsbad, California, USA) using PaIspS-Fw2 and PaIspS-Bw3 primers and specific internal primers (Appendix S4). Purifications of sequencing reactions products 260 Confirmation of sequence identity was performed by BLASTN search against the GenBank non261 redundant database using default parameters (Altschul et al. 1997). The resulting amino acid sequences were screened for the presence of specific residues that appear to be implicated in reducing active site volume in isoprene synthases relative to monoterpene synthases (Sharkey et al. 264 2013).

265 The eleven IspS coding sequences obtained from poplar and willow species where the EIVM was 266 also identified, together with sequences of the same gene from other plant species (Appendix S3) 
267 were aligned using ClustalX (Thompson et al. 1997). The phylogenetic analyses were conducted 268 using the software MEGA v.5.05 (Tamura et al. 2011). Maximum likelihood phylogenetic trees 269 (ML) were reconstructed and the reliability of tree branches was evaluated by using bootstrapping 270 271 with 9999 pseudo-replicates (Felsenstein 1985).

Further, a ds/dn analysis using SNAP (Synonymous (ds) vs Nonsynonymous (dn) Analysis Program) at 272 http://www.hiv.lanl.gov/content/sequence/SNAP/SNAP.html, which calculates the proportion of 273 synonymous substitutions per potential synonymous site and the proportion of nonsynonymous 274 substitutions per potential nonsynonymous site using the Nei and Gojobori method (Nei and 275 Gojobori 1986), was carried out.

276 By using the IspS phylogenetic tree, an Abouheif test of phylogenetic signal was performed to 277 evaluate whether the EIVM of the Salix and Populus species were related to changes in IspS 278 sequences at this taxonomic scale.

279

280

281

282

283

284

285

286

287

288

289

290

291

292

293

294

295

296

297

298

299

300

\section{RESULTS}

Among the woody species tested for emission of volatile isoprenoids, the proportion of isopreneemitting species was clearly higher in more hygrophilous EIVM classes, especially in class 8, where about $80 \%$ of the plants emit isoprene (Fig. 2a). The trend was opposite for the emission of monoterpenes, with monoterpene-emitters being found more often in the more xeric Ellenberg classes (Fig. 2b). The association between the two classes of volatile isoprenoids and the moisture level that characterize the habitats of the Mediterranean woody species was confirmed by a nonparametric Mann-Whitney Z-test. This test showed that the median EIVM is significantly higher in isoprene-emitting than in non-emitting species, while the EIVM is significantly lower in monoterpene emitters than in non-emitters (Fig. 3, p $<0.001$ in both cases).

A trend was also found when isoprenoid emission rates were attributed to EIVM classes. Plant species belonging to hygrophilous EIVM classes emitted more isoprene (Fig. 4a, p = 0.028), whereas the emission of monoterpenes was generally higher in the xeric EIVM classes (Fig. 4b, p= 0.030). However, when differences of emission rates among EIVM classes were assessed statistically, only isoprene was significantly different (Kruskal-Wallis non-parametric test, $\mathrm{p}=$ 0.0042, followed by post-hoc Dunn's Multiple Comparison Test showing differences between means of EIVM contrasting classes, e.g. 2-6 and 7-8). In the case of monoterpenes, the KruskalWallis test yielded non-significant differences $(\mathrm{p}=0.136)$, possibly because of the higher variability of the sampled emissions, and so we did not proceed with statistical mean separation among EIVM 
301 classes. The presence of monoterpene emitters with and without storage organs among the sampled 302 plant species might have contributed to make more variable the emission. As we only assessed 303 emissions, not contents, we did not separate monoterpene emitters according to the presence of 304 storage organs. The different emission rates of isoprenoids, as highlighted above, were not 305 associated with differences in the rates of photosynthesis among EIVM classes (data not shown).

306

307 Since isoprene-emitters of hygrophyte EIVM classes are dominated by Salicaceae, and 308 monoterpene-emitters of xeric EIVM classes mostly belong to Cistaceae and Pinaceae, a 309 phylogenetic analysis was carried out to understand how the phylogeny could have interacted with 310 the ecological signal.

311 Evidence of evolutionary conservatism in Ellenberg's indicator values was already found by 312 Prinzing et al. (2001). In agreement with this former report, the Abouheif test showed significant 313 phylogenetic signal in EIVM in our data set of woody species $(C=0.380, p=0.001 ; 999$ 314 permutations, 119 species). Likewise, the species also showed significant phylogenetic signal in 315 both isoprene and monoterpene emitting competence $(\mathrm{C}=0.547, \mathrm{p}=0.001$, and $\mathrm{C}=0.276, \mathrm{p}=$ 3160.001 for isoprene and monoterpene, respectively; in both cases 999 permutations and 128 species 317 were used). Accordingly, we may hypothesize that, at this broader phylogenetic scale, the species' 318 capability to adapt to more or less xeric terrestrial environments and their isoprenoid emissions are 319 both related to the evolutionary history of plants. In this view, EIVM and isoprenoids emissions 320 refer to large-scale environmental gradients, sensu Silvertown et al. (2006, Figure 1).

321 However, when controlling for phylogeny in the MCMCglmm analysis, we found that the presence 322 of isoprene emission is not associated with Ellenberg indicator values (binomial phylogenetic mixed 323 model: posterior mean 2.804 , lower $95 \%$ credibility interval -2.236 , upper $95 \%$ credibility interval 324 7.272, $\mathrm{p}=0.133$ ). This is most likely due to the overwhelming influence of closely related, 325 hygrophilous isoprene emitters (mainly Salicaceae) in the dataset. To the contrary, monoterpene 326 emission is significantly less frequent in hygrophytes (binomial phylogenetic mixed model: 327 posterior mean -0.465 , lower $95 \%$ credibility interval -0.882 , upper $95 \%$ credibility interval -0.124 , $328 \mathrm{p}<0.01$ ), suggesting that the evolution of monoterpene emission is associated with transitions to 329 more xeric habitats. The two traits (i.e. isoprene and monoterpene emission) were not significantly 330 related to each other (binomial phylogenetic mixed model with isoprene emission as dependent 331 variable: posterior mean: 3.146, lower 95\% credibility interval -23.604, upper 95\% credibility 332 interval 28.925, $\mathrm{p}=0.711$ ), which suggests that the two traits are not complementary and their 333 evolution is probably determined by separate ecological factors. 
334 Since isoprene emitters belonging to Populus and Salix genera were clearly distributed along the 335 gradient of hygrophily, we further explored whether this distribution was associated with 336 phylogenetic differences, as inferred from differences in the isoprene synthase gene. Eleven partial

\section{DISCUSSION} genomic isoprene synthase sequences were identified in Populus and Salix species (Appendix S3). All sequences displayed high degree of homology (from 95\% to 100\%) with already available $I s p S$ sequences. All the sequences were screened for the presence of two Phe residues that are involved in reducing active site volume in isoprene synthases relative to monoterpene synthases (Sharkey $e t$ al. 2013). In addition, SNAP analysis demonstrated higher ds than $\mathrm{dn}$ in all sequences (average $\mathrm{ds} / \mathrm{dn}$ pairwise comparison ratio $=8.29$ ).

Phylogenetic analysis was carried out by using the coding sequences of IspS of Populus and Salix species isolated in this study, together with poplar sequences available in GenBank (http://www.ncbi.nlm.nih.gov/genbank/) (listed in Appendix S3). When using Vitis vinifera and Pueraria montana as outgroups, the ingroup turned out to be monophyletic even if the relative position of the two outgroups has low bootstrap support. Two main clades were identified within the in-group, one clustering most Populus species and the other clustering Salix species (Fig. 5a, b). Furthermore, within the Populus clade, the species grouped according to section classification based on other markers (Eckenwalder 1996). An exception was represented by P. nigra, which was grouped within the Populus section in spite of being classified as a member of the Ageiros section (Eckenwalder, 1996). The ecological adaptation trait, as marked by the EIVM classes, and the pattern of nucleotide changes in IspS were not associated in poplar and willow species (Fig. 5b). This was further confirmed by the non-significant results of the Abouheif test (Abouheif $\mathrm{C}=0.033$; $\mathrm{p}=0.357)$.

An association between isoprene emission and hygrophily was suggested by several independent observations: a) that isoprene is emitted at higher rates in hygrophyte forest plants than in more xeric plants of transitional woodlands and savannahs, e.g. in central Africa (Greenberg et al. 1999); (b) that isoprene emission is generally more common in fast-growing, water-spending species (Vickers et al. 2009). Perhaps this is in turn related to the phloem-loading mechanism, because isoprene emitters are characterized by symplastic phloem loading (Kerstiens \& Possell 2001). Whether this trait is also related to fast-growth and hygrophily should be investigated; c) that isoprene emission is more common in mosses than in other clades of plants (Hanson et al. 1999). Hanson et al. (1999) suggested that isoprene emission by plants could have been an important 
ancient mechanism of adaptation to terrestrial environment that increased tolerance to thermal stresses in environments not buffered by water. Vickers et al. (2009) argued that isoprene could also have helped early land plants cope with high oxidative stress in the atmosphere. Indeed, isoprene emission is more common and the emission rates are higher in the hygrohytes of the Italian flora that we have tested. Emission rates expressed on a leaf area basis are reported here, but the trend would hold when expressing isoprene emission on a leaf mass basis, as leaves of hygrophytes are generally thinner than in xerophytes. An exception to this trend was found in EIVM class 1 . However, this xeric class includes only three species, and only one isoprene-emitting species, Chamaerops humilis, which is the sole representative of Arecaceae (the palm family) in mainland-Europe. This taxon evolved in moist tropical climates of the rain-forest biome, where it still harbors its highest diversity; most palms have a very low drought-tolerance, and the few species adapted to dry habitats are probably the result of recent radiation (Eiserhardt et al. 2011). Interestingly, a similar reasoning might apply to Myrtus communis, the only emitter found in EIVM class 2 (out of 16 tested taxa in this class), as this is the only European member of the tropical family Myrtaceae (Biffin et al. 2010). However, our large-scale phylogenetic analysis does not support the ecological value of these observations, because of the strong phylogenetic signal in isoprene emission; for instance, most isoprene emitting species in the more hygrophilous Ellenberg categories belong to Salicaceae (see Appendix S1). As the evolution of isoprene emission is not associated with evolutionary adaptation to hygrophily, our data suggests that resistance to other environmental factors (such as coping with thermal or oxidative stresses (Vickers et al. 2009)) might characterize isoprene emitters. On the other hand, our analysis has shown that, when the phylogenetic relationships are taken into account, monoterpene emission is more common in xeric species of the Italian woody flora, suggesting that monoterpenes evolved in arid habitats, independently on whether the emission of monoterpenes occurs from storage pools or directly from photosynthesis, in a light-dependent way. Thus, different classes of isoprenoids might have evolved in response to different environmental factors, rather than being complementary of each other.

It is unclear why the isoprene emission trait has been lost multiple times in terrestrial plants (Harley et al. 1999, Sharkey et al. 2005, Sharkey et al. 2013). Monson et al. (2013) recently noted that the high frequency of loss might indicate that isoprene emission is a favorable trait only in a limited number of environments, or for few plants. As monoterpenes and non-volatile isoprenoids are 400 effective antioxidants protecting plants from many abiotic and biotic stressors (Vickers et al. 2009), 401 our observations suggest that isoprene is synthesized and emitted only when more effective 402 mechanisms of stress protection, especially regarding stress conditions associated with xerophily, 
403 are not active. In fact, as shown in Appendix S1, most plant species emit either isoprene or 404 monoterpenes, not both. The trade-off between isoprene and monoterpenes was also observed by 405 Harrison et al. (2013) in a survey that was carried out at worldwide level, and therefore emerges as 406 an important feature, not limited to Mediterranean conditions. The emission of monoterpenes seems 407 to be a successful trait in alien species invading new territories, possibly again due to the ability of 408 monoterpenes of conferring resistance against multiple stresses (Llusia et al. 2010). At a finer taxonomic scale, we then explored whether the hygrophily of isoprene emitters, as indicated by species assignment to the Ellenberg classes, showed phylogenetic signal within Salicaceae. Specifically, we tested whether isoprene emitters, phylogenetically close with respect to IspS, also shared similar EIVM classes. However, the distribution of EIVM classes was not associated to the phylogenetic patterns of IspS. We therefore hypothesize that IspS has not undergone convergent evolution linked to ecological pressure, namely to adaptation to xeric environments. Perhaps genes at earlier stages of the chloroplastic isoprenoid pathway are more pleiotropic and are therefore subjected to heavier selective pressure than IspS (Ramsay et al. 2009), or regulation of gene expression or enzyme activation, rather than gene sequence, provides sufficient response to changes in hygrophily.

On the other hand, the phylogeny based on IspS showed that poplar and willow species could be properly separated, indicating a strong match with taxonomic information (Eckenwalder 1996), and confirming the value of genes underlying volatile isoprenoid biosynthesis as chemo-taxonomical markers (Loreto et al. 2009). A relevant exception to the clear match between IspS phylogeny and taxonomy in Mediterranean poplar species is represented by P. nigra, which grouped within the section Populus in spite of being a member of the section Ageiros, maybe as a consequence of its hybrid origin (Smith \& Sytsma 1990).

The public availability of IspS sequences in GenBank made it possible to match the phylogenies of our Mediterranean poplars with those of non-European poplars. The resulting ML tree showed that gene identity between poplars of different regions of the world is higher than the identity between genera sharing the same ecological environment. Moreover, P. euphratica, a species adapted to desert conditions (Qiu et al. 2011) was phylogenetically very distant from Mediterranean species that are adapted to xeric conditions. Accordingly, changes in IspS sequences on poplars of different habitats strongly reflect the species' phylogenetic relationships rather than ecological adaptation. 
437 ancestral isoprene-emission character. A similar conclusion was reached when analyzing isoprenoid 438 emissions in oaks (Loreto et al. 1998; Loreto et al. 2009). Similarly, also monoterpene-emitting 439 taxa, like e.g. the few Betula species that can be found in the Mediterranean area, in clearly 440 hygrophytic habitats, may have retained this trait due to a strong phylogenetic signal rather than 441 with their present-day ecological distribution.

442 In conclusion, we surmise that biosynthesis and emission of different volatile isoprenoids have 443 likely evolved in response to different stimuli. Isoprene likely has evolved independently many 444 times, characterizing about all vascular plants, from ferns to angiosperms. It might be a primitive 445 adaptive trait to terrestrial life, which might not have further evolved in response to more recent 446 ecological pressures, being rather lost in favor of more effective protective mechanisms, in 447 agreement with the 'opportunistic' hypothesis put forward by Owen \& Peñuelas (2005). 448 Monoterpenes might have evolved to adapt to xeric environments and might yet be an important 449 adaptive trait in response to drought in the Mediterranean flora. Further studies are needed to test 450 these conclusions, both completing the current survey of European flora, and, at an even wider 451 level, providing more data about vegetation worldwide.

452

453

454 455 456 457 458 459 460 461 462 463 464 465 466 467 468 469 470

\section{ACKNOWLEDGMENTS}

Mauro Medori, Lucia Michelini and Isabel Nogues helped with sample collection and measurements. Pietro Bianco provided an early version of the data-base of the Italian woody flora. Salvatore Cozzolino provided valuable comments on the manuscript. Costantino Bonomi at the Museo delle Scienze, Trento, and the staff at the Ufficio Territoriale per la Biodiversità, Belluno, are gratefully acknowledged for providing samples of Salix species. Arie Altman kindly provided DNA samples of Populus euphratica. Riikka Rinnan kindly provided specimens of Salix reticulata from boreal latitudes. This work was supported by the European Science Foundation Eurocores programme "Ecology of Plant Volatiles (EuroVOL)", project "Molecular and metabolic bases of volatile isoprenoid emissions (MOMEVIP)", by the European Commission - FP7 project "Development of improved perennial non-food biomass and bioproduct crops for water stressed environments" (WATBIO), and by the Italian Ministry of University and Research PRIN 2011 project: "Going to the root of plant productivity: how the rhizosphere interact with the aboveground armament for indirect and direct defense against abiotic and biotic stressors" (PRO-ROOT). 
471

472

473

474

475

476

477

478

479

480

481

482

483

484

485

486

487

488

489

490

491

492

493

494

495

496

497

498

499

500

501

502

503

504

\section{REFERENCES}

Abouheif, E. (1999) A method for testing the assumption of phylogenetic independence in comparative data. Evoutionary Ecology Research, 1, 895-909.

Altschul, S.F., Madden, T.L., Schäffer, A, Zhang, J., Zhang, Z., Miller, W. \& Lipman D.J. (1997) Gapped BLAST and PSI-BLAST: a new generation of protein database search programs. Nucleic Acids Researc, 25, 3389-3402.

Bennet, K., Tzedakis, P. \& Willis, K. (1991) Quaternary refugia of north European trees. Journal of Biogeography, 18, 103-115.

Biffin, E., Lucas, E.J., Craven, L.A., Ribeiro da Costa, I., Harrington, M.G. \& Crisp, M.D. (2010) Evolution of exceptional species richness among lineages of fleshy-fruited Myrtaceae. Annals of Botany, 106, 79-93.

Blondel, J. \& Aronson, J. (1999) Biology and Wildlife of the Mediterranean Region. Oxford University Press, Oxford.

Böhling, N., Greuter, W. \& Raus, T. (2002) Zeigerwerte der Gefäßpflanzen der Südägäis (Griechenland) [Indicator values of the vascular plants in the Southern Aegean (Greece)]. BraunBlanquetia, 32, 1-106.

Comes, H.P. (2004) The Mediterranean region - a hotspot for plant biogeographic research. New Phytologist, 164, 11-14.

Conti, F., Abbate, G., Alessandrini, A., \& Blasi, C. (2005) An annotated checklist of the italian vascular flora. Palombi Editore, Roma.

Dicke, M. \& Baldwin, I.T. (2010) The evolutionary context for herbivore-induced plant volatiles: beyond the 'cry for help'. Trends in Plant Science, 15, 167-175.

Diekmann, M. (2003) Species indicator values as an important tool in applied plant ecology - a review. Basic and Applied Ecology, 4, 493-506.

Duprè, C., Stevens, C., Ranke, T., Leeker, A., Peppeler-Lisbach, C., Gowing, D., Dise, N.B., Dorland, E., Bobbink, R. \& Diekmann, M. (2010) Changes in species richness and composition in European acidic grasslands over the past 70 years: the contribution of cumulative atmospheric nitrogen deposition. Global Change Biology, 16, 344-357.

Eckenwalder, J. (1996) Systematics and evolution of Populus. Biology of Populus and its implication for management and conservation (ed. by H. Stettler, J. Bradshaw and P.H.T. Heilman),pp.7-32. NRC Research Press, Ottawa.

Eiserhardt, W.L., Svenning, J.C., Kissling, W.D. \& Balslev, H. (2011) Geographical ecology of the palms (Arecaceae): determinants of diversity and distributions across spatial scales. Annals of Botany, 108, 1391-1416. 
505 Ellenberg, H. (1974) Zeigerwerteder Gefäßpflanzen Mitteleuropas. Scripta Geobotanica, 9, 1-94.

506 Ellenberg, H., Weber, H., Düll, R., Wirth, V., Werner, W., \& Paulissen, D., (1991) Zeigerwerte der 507 Pflanzen von Mitteleuropa. Scripta Geobotanica, 18, 1-248.

508 Fanelli, G., Pignatti, S. \& Testi, A. (2007) An application case of ecological indicator values 509 (Zeigerwerte) calculated with a simple algorithmic approach. Plant Biosystems, 141, 15-21.

510 Felsenstein, J. (1985) Confidence limits on phylogenesis: an approach using the bootstrap. 511 Evolution, 39, 791.

512 Fineschi, S. \& Loreto, F. (2012) Leaf volatile isoprenoids: an important defensive armament in 513 forest tree species. iForest, 5, 13-17.

514 Fineschi, S., Loreto, F., Staudt, M. \& Penuelas, J. (2013) Diversification of volatile isoprenoid 515 emissions from trees: evolutionary and ecological perspectives. Biology, controls and models of 516 tree volatile organic compound emissions (ed. by U. Niinemets and R.K. Monson), pp. 1-20. 517 Springer, Dordrecht, Germany.

518 Fortunati, A., Barta, C., Brilli, F., Centritto, M., Zimmer, I., Schnitzler, J.P. \& Loreto F. (2008) 519 Isoprene emission is not temperature-dependent during and after severe drought-stress: a 520 physiological and biochemical analysis. Plant Journal, 55, 687-697.

521 Godefroid, S. \& Dana, E.D. (2007) Can Ellenberg's indicator values for Mediterranean plants be 522 used outside their region of definition? Journal of Biogeography, 34, 62-68.

523 Greenberg, J.P., Guenther, A.B., Madronich, S., Baugh, W., Ginoux, P., Druilhet, A., Delmas, R. \& 524 Delon, C. (1999) Biogenic volatile organic compound emissions in central Africa during the 525 experiments for the regional sources and sinks of oxidants (EXPRESSO) biomass burning 526 season. Journal of Geophysical Research, 104, 30659-30671.

527 Hadfield JD (2010). MCMC Methods for Multi-Response Generalized Linear Mixed Models: The 528 MCMCglmm R Package. Journal of Statistical Software, 33, 1-22.

529 Hanson, D.T., Swanson, S., Graham, L.E. \& Sharkey, T.D. (1999) Evolutionary significance of $530 \quad$ isopreneemission from mosses. America Journal of Botany, 86, 634-639.

531 Harley, P.C., Monson, R.K. \& Lerdau, M.T. (1999) Ecological and evolutionary aspects of isoprene 532 emission from plants. Oecologia, 118, 109-123.

533 Harrison S.P., Morfopoulos C., Srikanta Dani K.G., Prentice I. C., Arneth A., Atwell B.J., Barkley 534 M.P., Leishman M.R., Loreto F., Medlyn B.E., Niinemets Ü., Possell M., Peñuelas J., \& Wright 535 I.J. (2013) Volatile isoprenoid emissions from plastid to planet. New Phytologist, 197, 49-57.

536 Hill, M., Mountford, J., Roy, D. \& Bunce, R. (1999) Ellenberg's indicator values for British Plants. 537 Institute of Terrestrial Ecology, Huntingdon. 
538 Jones, M.L., Hayes, F., Mills, G., Sparks, T.H. \& Fuhrer, J. (2007) Predicting community 539 sensitivity to ozone, using Ellenberg Indicator values. Environmental Pollution, 146, 744-753.

540 Kerstiens, G., \& Possell, M. (2001) Is competence for isoprene emission related to the mode of 541 phloem loading? New Phytologist, 152, 368-372.

542 Kesselmeier, J. \& Staudt, M. (1999) Biogenic Volatile Organic Compounds (VOC): An overview 543 on emission, physiology and ecology. Journal of Atmospheric Chemistry, 33, 23-88.

Klaus, V., Kleinebecker, T., Boch, S., Müller, J., Socher, S.A., Prati, D., Fischer, M. \& Hölzel, N. (2012) NIRS meets Ellenberg's indicator values: Prediction of moisture and nitrogen values of agricultural grassland vegetation by means of near-infrared spectral characteristics. Ecological Indicators, 14, 82-86.

Krecek, J., Novakova, J. \& Horicka, Z. (2010) Ellenberg's indicator in water resources control: The Jizera Mountains, Czech Republic. Ecological Engineering, 36, 1112-1117.

Llusiá, J., Peñuelas, J., Sardans, J., Owen, S.M. \& Niinemets, U. (2010) Measurement of volatile terpene emissions in 70 dominant vascular plant species in Hawaii: aliens emit more than natives. Global Ecology and Biogeography, 19, 863-874.

Loreto, F., Bagnoli, F. \& Fineschi, S. (2009) One species, many terpenes: matching chemical and biological diversity. Trends in Plant Science, 14, 416-420.

Loreto, F., Ciccioli, P., Brancaleoni, E., Valentini, R., De Lillis, M., Csiky, O. \& Seufert, G. (1998) A hypothesis on the evolution of isoprenoid emission by oaks based on the correlation between emission type and Quercus taxonomy. Oecologia, 115, 302-305.

Loreto, F. \& Schnitzler, J.P. (2010) Abiotic stresses and induced BVOCs. Trends in Plant Science, 15, 154-166.

Loreto, F. \& Velikova, V. (2001) Isoprene produced by leaves protects the photosynthetic apparatus against ozone damage, quenches ozone products, and reduces lipid peroxidation of cellular membranes. Plant Physiology, 127, 1781-1787.

Médail, F. \& Diadema, K. (2009) Glacial refugia influence plant diversity patterns in the Mediterranean Basin. Journal of Biogeography, 36, 1333-1345.

Médail, F. \& Quézel, P. (1999) Biodiversity hotspots in the Mediterranean basin: Setting global conservation priorities. Conservation Biology, 13, 1510-1513.

Monson, R.K., Jones, R.T., Rosenstiel, T.N. \& Schnitzler, J.P. (2013) Why only some plants emit isoprene. Plant, Cell \& Environment, 36, 503-516.

Nei M. \& Gojobori T. (1986) Simple methods for estimating the numbers of synonymous and nonsynonymous nucleotide substitutions. Molecular Biology and Evolution, 5, 418-426. 
571 Niinemets, U., Loreto, F. \& Reichstein, M. (2004) Physiological and physicochemical controls on 572 foliar volatile organic compound emissions. Trends in Plant Science, 9, 180-186.

573 Owen, S.M. \& Peñuelas, J. (2005) Opportunistic emissions of volatile isoprenoids. Trends in Plant 574 Science, 10, 420-426.

575 Pignatti, S. (1982) Flora d'Italia. Edagricole, Bologna.

576 Pignatti, S., Menegoni, P. \& Pietrosanti, S. (2005) Bioindicazione attraverso le piante 577 vascolari.Valori di indicazione secondo Ellenberg (Zeigerwerte) per le specie della Flora d'Italia. 578 Braun-Blanquetia, 39, 1-97.

579 Prinzing, A., Durka, W., Klotz, S. \& Brandl, R. (2001) The niche of higher plants: evidence for 580 phylogenetic conservatism. Proceedings of the Royal Society of London B, 268, 2383-2389.

581 Qiu, Q., Ma, T., Hu, Q., Liu, B., Wu, Y., Zhou, H., Wang, Q., Wang, J., Liu, J. \& Sederoff, R. 582 (2011) Genome-scale transcriptome analysis of the desert poplar, Populus euphratica. Tree 583 Physiology, 31, 452-461.

584 Ramsay, H., Rieseberg, L.H. \& Ritland, K. (2009) The correlation of evolutionary rate with 585 pathway position in plant terpenoid biosynthesis. Molecular Biology and Evolution, 26, 10455861053.

587 R Core Team (2012). R: A language and environment for statistical computing. R Foundation for 588 Statistical Computing, Vienna, Austria. http://www.R-project.org.

589 Schaffers, A. \& Sýcora, K. (2000) Reliability of Ellenberg indicator values for moisture, nitrogen 590 and soil reaction: a comparison with field measurements. Journal of Vegetation Science, 11, 225591244.

592 Schmidtlein, S. (2005) Imaging spectroscopy as a tool for mapping Ellenberg indicator values. 593 Journal of Applied Ecology, 42, 966-974.

594 Sharkey, T.D., Yeh, S., Wiberley, A.E., Falbel, T.G., Gong, D. \& Fernandez, D.E. (2005) Evolution 595 of the Isoprene Biosynthetic Pathway in Kudzu. Plant Physiology, 137, 700-712.

596 Sharkey, T.D., Gray, D.W., Pell, H.K., Breneman, S.R., \& Toppers L. (2013) Isoprene synthase 597 genes form a monophyletic clade of acyclic terpene synthases in the TPS-b terpene synthase 598 family. Evolution doi:10.1111/evo.12013.

599 Silver, G.M. \& Fall, R. (1995) Characterization of aspen isoprene synthase, an enzyme responsible 600 for leaf isoprene emission to the atmosphere. Journal of Biological Chemistry, 270, 13010$601 \quad 13016$.

602 Silvertown, J., Dodd, M., Gowing, D., Lawson, C. \& McConway, K. (2006) Phylogeny and the 603 Hierarchical Organization of Plant Diversity. Ecology, 87, S39-S49. 
604 Singsaas, E.L., Lerdau, M., Winter, K. \& Sharkey, T.D. (1997) Isoprene increases thermotolerance 605 of isoprene-emitting species. Plant Physiology, 115, 1413-1420.

606 Smith, R. \& Sytsma, K. (1990) Evolution of Populus nigra (sect. Aigeiros): introgressive 607 hybridization and the chloroplast contribution of Populus alba (sect. Populus). American Journal 608 of Botany, 77, 1176-1187.

609 Stevens, P.F. (2001) onwards. Angiosperm Phylogeny Website. Version 12, July 2012.

610 Sullivan, C.A., Skeffington, M.S., Gormally, M.J. \& Finn, J.A. (2010) The ecological status of 611 grasslands on lowland farmlands in western Ireland and implications for grassland classification 612 and nature value assessment. Biological Conservation, 143, 1529-1539.

613 Tamura, K., Peterson, D., Peterson, N., Stecher, G., Nei, M. \& Kumar, S. (2011) MEGA5: 614 Molecular Evolutionary Genetics Analysis using Maximum Likelihood, Evolutionary Distance, 615 and Maximum Parsimony Methods. Molecular Biology and Evolution, 28, 2731-2739.

616 Thompson, J. (2005) Plant Evolution in the Mediterranean. Oxford University Press, Oxford.

617 Thompson, J.D., Gibson, T.J., Plewniak, F., Jeanmougin, F. \& Higgins, D.G. (1997) The 618 CLUSTAL_X Windows Interface: Flexible strategies for multiple sequence alignment aided by 619 quality analysis tools. Nucleic Acids Research, 25, 4876-4882.

620 Velikova, V., Varkonyi, Z., Szabò, M., Maslenkova, L., Nogues, I., Kovacs, L., Peeva, V., 621 Busheva, M., Garab, G., Sharkey, T.D. \& Loreto, F. (2011) Increased thermostability of 622 thylakoid membranes in isoprene-emitting leaves probed with three biophysical techniques. 623 Plant Physiology, 157, 905-916.

624 Vickers, C.E., Gershenzon, J., Lerdau, M.T. \& Loreto, F. (2009) A unified mechanism of action for 625 volatile isoprenoids in plant abiotic stress. Nature Chemical Biology, 5, 283-291. 


\section{BIOSKETCHES}

627

628 Francesco Loreto is currently the director of the Department of Biology, Agriculture and Food 629 Sciences at the Italian National Research Council. His work spans plant physiology and ecology 630 with a special interest on the functions and metabolism of volatile isoprenoids.

631 FL conceived and designed the experiments. FB, DC, JT, GS and SF conducted the phylogenetic 632 analysis, CC and GG performed eco-physiological measurements. MDL prepared the first database 633 of isoprenoids emission by woody species, which was revised by GF, and used as a template for 634 ecological assignment of plants by GF and GG. CR performed biostatistics. FL and CR wrote the 635 paper, and all authors contributed to the editing.

636

637 
639 FIGURE LEGENDS

640

641 Figure 1. Cladogram describing, for the 128 species subjected to broad-scale phylogenetic analysis, 642 phylogenetic position, isoprenoid emissions capability (black circles; $\mathrm{i}=$ isoprene emitter, $\mathrm{m}=$ 643 monoterpene emitter), and Ellenberg indicator values for moisture (EIVM).

644

Figure 2. Fraction of isoprene (A) and monoterpene (B) emitters in the different classes of the 646 647 woody plant species of the Italian flora as ranked for hygrophily according to the Ellenberg indicator values for moisture (EIVM: $1=$ driest; 12 = wettest). Main families of isoprene (Salicaceae) and monoterpene (Pinaceae, Cistaceae and Betulaceae) emitters are shown with 650

Figure 3. Box plots of the distribution in classes of Ellenberg indicator values for moisture (EIVM) 652 of isoprene (grey) and monoterpene (white) emitters versus non-emitters of the woody Italian flora 653 (see Figure 1). Boxes indicate 25-75 percentiles of the collected data. The lines inside boxes 654 indicate the median values. Bars outside boxes indicate the 5-95 percentiles of data, and circles 655 indicate outlier data. A non-parametric Mann-Whitney Z-test was used for comparing median 656 EIVM between emitters and non-emitters. Significant differences with respect to non-emitters were 657 found for both isoprene-emitters $(Z=3.403 ; p<0.001)$, and monoterpene-emitters $(Z=-4.125 ; p<$ 658 0.001). The latter is significant also after phylogenetic control, confirming the ecological relevance 659 of this finding, while this is not the case for isoprene (see Results).

660

661 Figure 4. Emission rates of isoprene (A) and monoterpenes (B) by woody species of the flora of 662 Italy ranked according to the Ellenberg indicator values for moisture (EIVM). The means and 663 standard errors of data collected through field measurements $(n \geq 3)$ and surveys of available data 664 sets are shown. Best fits based on linear regressions are shown, together with regression 665 coefficients. The best fit lines showed a statistically significant trend toward higher emission of 666 isoprene in hygrophytes $(\mathrm{p}=0.028)$ and higher emission of monoterpenes in xerophytes $(\mathrm{p}=$ 667 0.030). Further statistical analysis confirmed isoprene emission rates to be higher in hygrophytes 668 (Kruskal-Wallis non-parametric test, $\mathrm{p}=0.0042$ ), and statistically significant among EIVM classes 669 (Dunn's Multiple Comparison Test, significantly different means are shown by different letters, $\mathrm{p}=$ 6700.05 ; class 1 was not included in the post-hoc test due to the low sample size (only one emitting 671 species, as shown in the text)). The Kruskal-Wallis test yielded non-significant differences $(\mathrm{p}=$ 
672 0.136) for monoterpenes, and therefore no test was performed to separate EIVM classes of 673 monoterpene-emitters.

674

675 Figure 5. Phylogenetic tree based on IspS coding sequences identified in this study for Populus and 676 Salix species of the Italian flora (A). The numbers close to each species name refer to Ellenberg 677 indicator values for moisture (n.a. = not available). The numbers next to each node are the bootstrap 678 percentages from 10000 pseudo-replicates. Only bootstrap values above $50 \%$ are presented on the 679 tree. In (B) the phylogenetic tree based on available IspS coding sequences of Populus and Salix 680 species is widened to compare with non-European poplar species, and with two outgroup species 681 whose $I s p S$ sequence is also known. Black dots refer to sequences obtained in this research. The 682 sections Populus (P), Aigeiros (A), Tacamahaca (Ta) and Turanga (Tu) are also indicated in (B). 


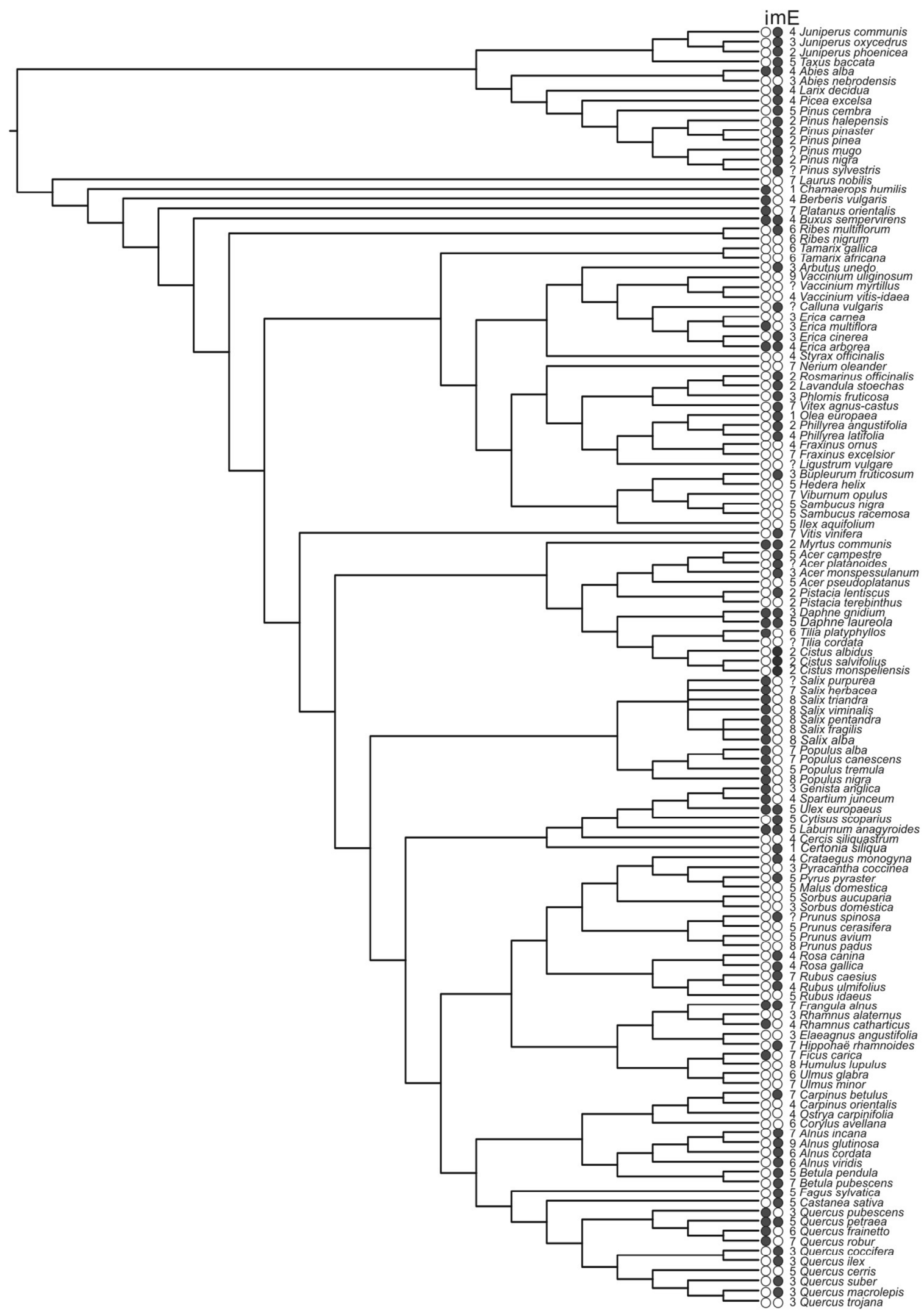

685 Figure 1

686 
687

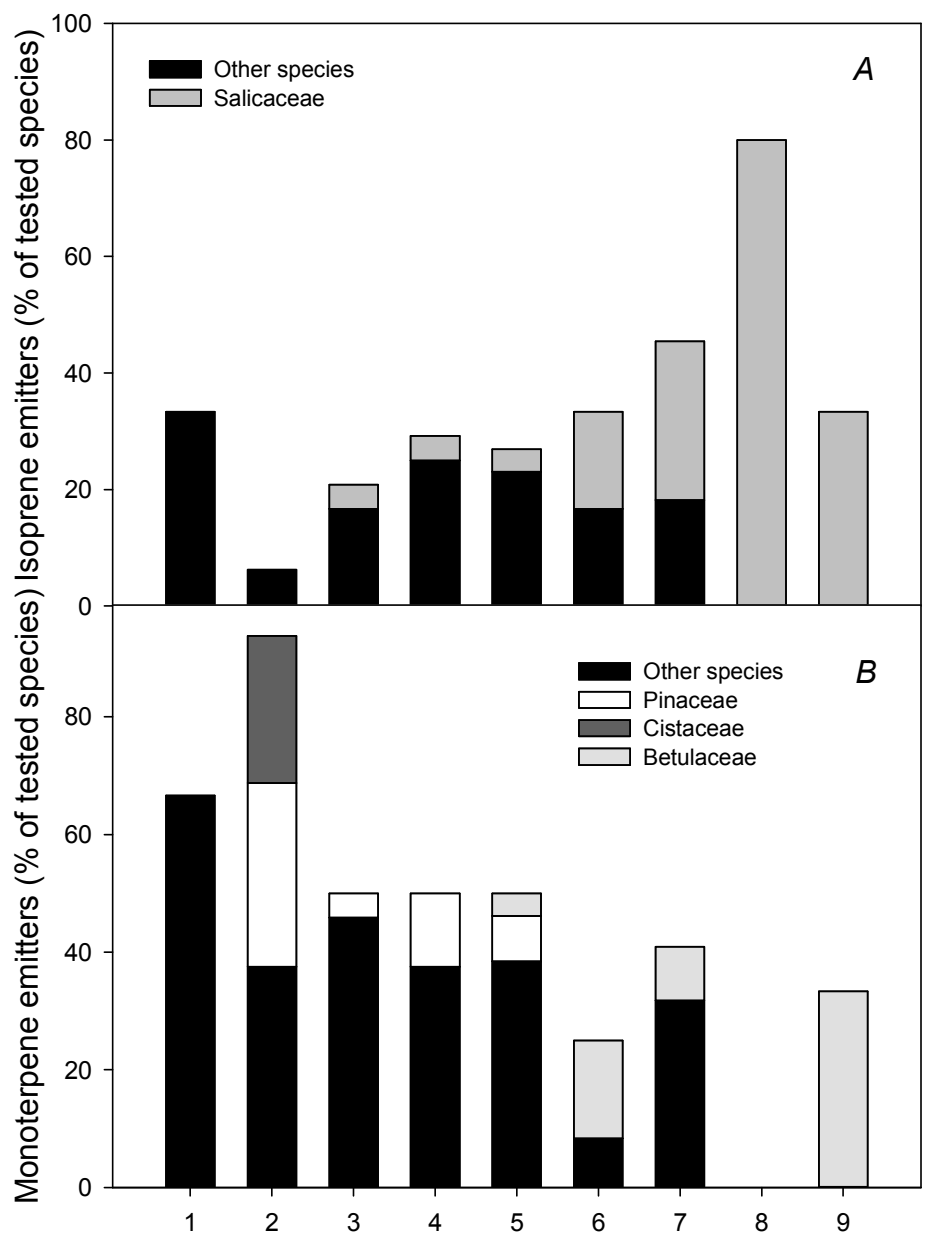

688

Ellenberg Indicator Value for Moisture

689

690 Figure 2

691

42

43

44

45

46

47

48

49

50

51

52

53

54

55

56

57

58

59

60 
692

1

2

3

4

5

6

7

8

9

10

11

12

13

14

15

16

17

18

19

20

21

22

23

24

25

26

27

28

29

30

31

32

33

34

35

36

37

38

39

40

41

42

43

44

45

46

47

48

49

50

51

52

53

54

55

56

57

58

59

60

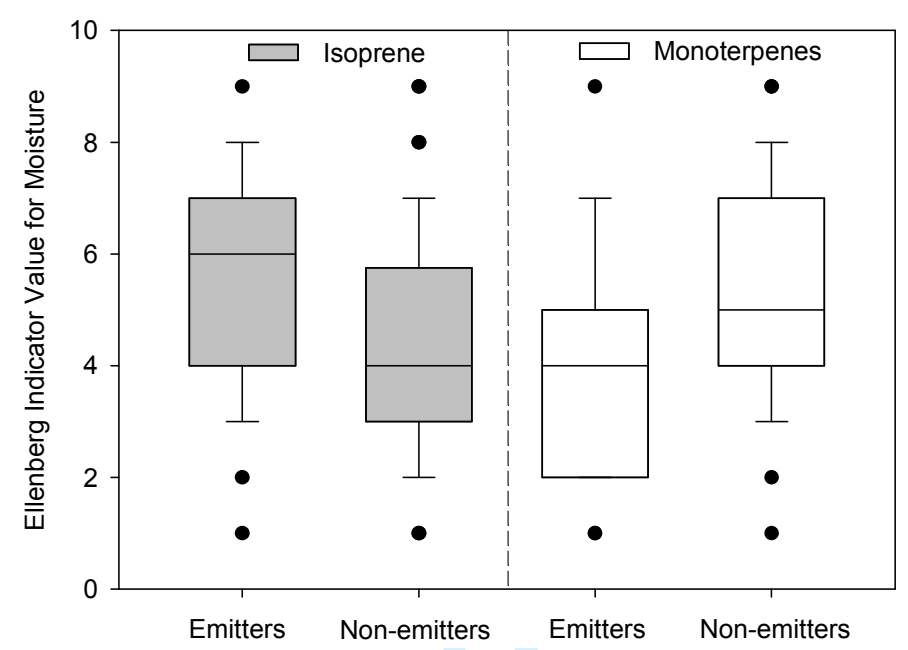

693

694

695

696

Figure 3. 
697

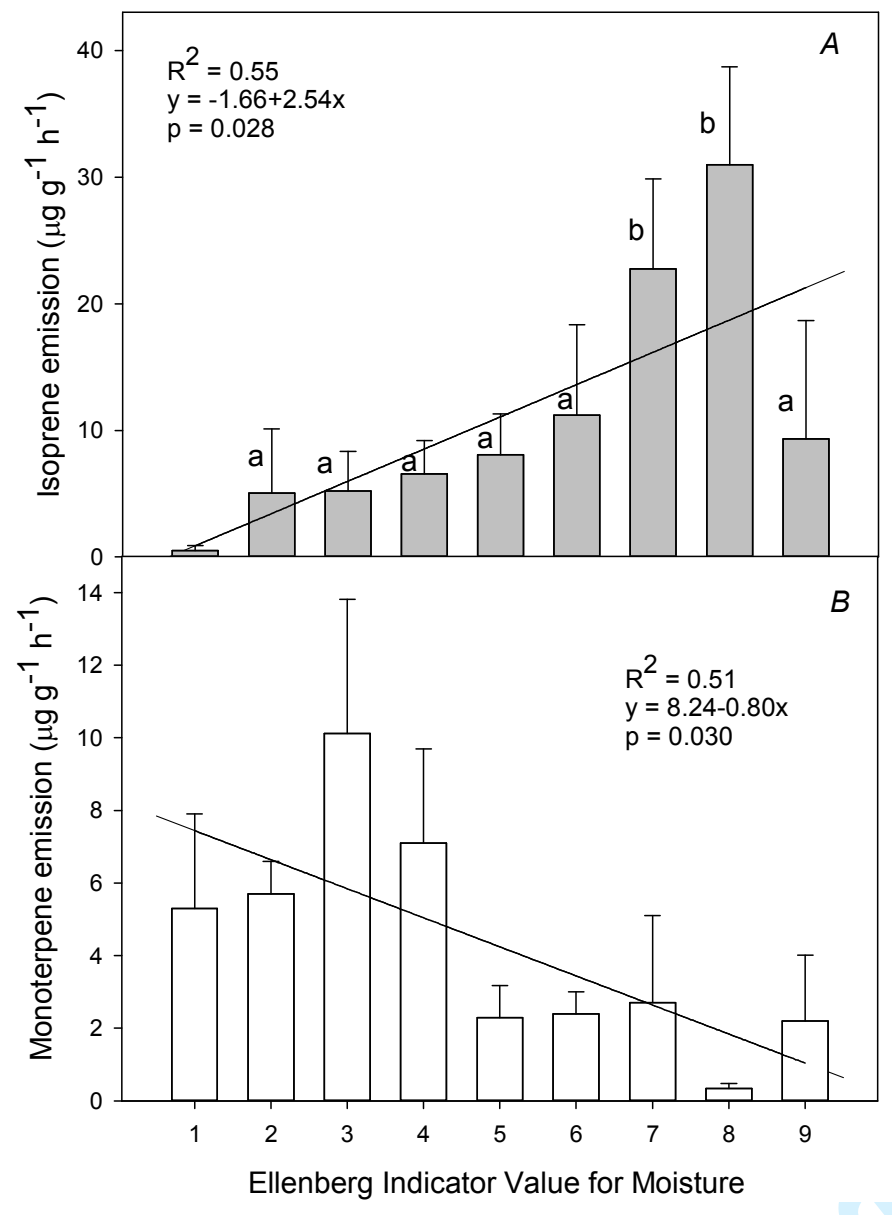

Figure 4.

37

38

39

40

41

42

43

44

45

46

47

48

49

50

51

52

53

54

55

56

57

58

59 
1

2

3

4

5

6

7

8

9

10

11

12

13

14

15

16

17

18

19

20

21

22

23

24

25

26

27

28

29

30

31

32

33

34

35

36

37

38

39

40

41

42

43

44

45

46

47

48

49

50

51

52

53

54

55

56

57

58

59

60
702

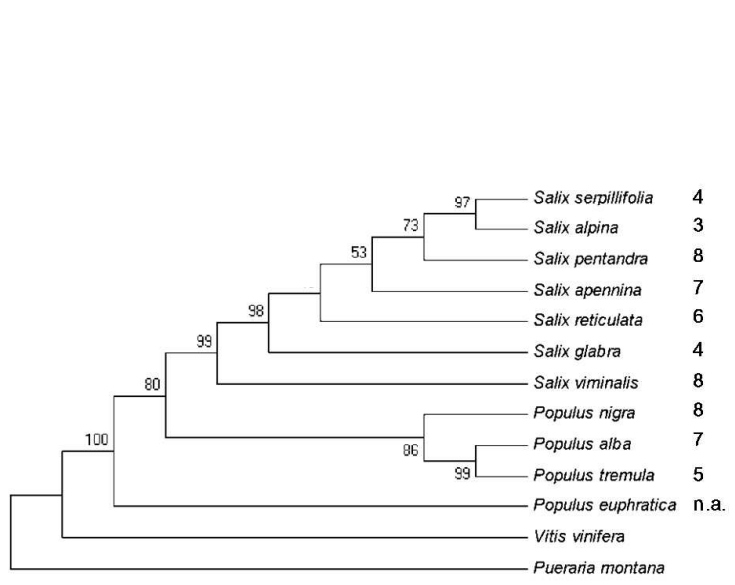

A

703

704

705

706

Figure 5.

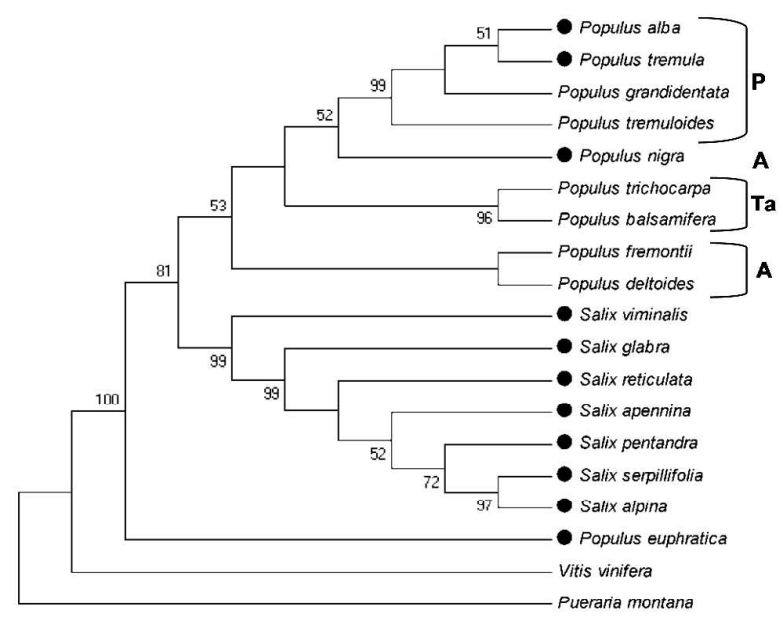

B 


\title{
Isoprenoid emission in hygrophyte and xerophyte European woody flora:
} ecological and evolutionary implications

\author{
Francesco Loreto $^{1^{*}}$, Francesca Bagnoli ${ }^{2}$, Carlo Calfapietra ${ }^{3}$, Donata Cafasso ${ }^{4}$, Manuela De \\ Lillis $^{1}$, Goffredo Filibeck ${ }^{5}$, Silvia Fineschi ${ }^{2}$, Gabriele Guidolotti ${ }^{6}$, Gábor Sramkó ${ }^{7}$, Jácint \\ Tökölyi ${ }^{8}$, Carlo Ricotta ${ }^{9}$
}

\section{SUPPORTING INFORMATION}

Appendix S1. Attribution of woody species of the flora of Italy to classes of Ellenberg Indicator Values for Moisture (EIVM; 1 to 9 is the incremental scale for moisture, ? indicates species that tolerate a wide range of moisture conditions), and to isoprenoid emission types ( $\mathrm{I}=$ isoprene; $\mathrm{M}=$ monoterpenes; $\mathrm{NE}=$ non-emitter; $\mathrm{NA}=$ data not available). The superscripted number indicates references are available, as reported at the end of the table.

\begin{tabular}{|c|c|c|c|}
\hline Family & Species & EIVM & $\frac{\text { Isoprenoid }}{\text { Emission }}$ \\
\hline Pinaceae & Abies alba Miller & $\underline{4}$ & $\underline{1+M^{3}}$ \\
\hline Pinaceae & Abies nebrodensis (Lojac.) Mattei & $\underline{3}$ & $\mathrm{NE}^{2}$ \\
\hline Aceraceae & Acer campestre L. & $\underline{5}$ & $\overline{\mathrm{M}^{3}}$ \\
\hline Aceraceae & Acer lobelii Ten. & $\underline{5}$ & $\underline{\mathrm{NA}}$ \\
\hline Aceraceae & Acer monspessulanum L. & $\underline{3}$ & $\mathrm{M}^{3}$ \\
\hline Aceraceae & Acer obtusatum W. et K. & $\underline{4}$ & $\mathrm{M}^{1}$ \\
\hline Aceraceae & Acer platanoides $\mathrm{L}$. & $\underline{?}$ & $\mathrm{M}^{3}$ \\
\hline Aceraceae & Acer pseudoplatanus L. & $\underline{5}$ & $\mathrm{NE}^{4}$ \\
\hline Fabaceae & Adenocarpus complicatus (L.) Gay & $\underline{3}$ & $\mathrm{NA}$ \\
\hline Betulaceae & Alnus cordata (Loisel.) Desf. & $\underline{6}$ & $\underline{M}^{3}$ \\
\hline Betulaceae & Alnus glutinosa (L.) Gaertner & $\underline{9}$ & $\mathrm{M}^{1}$ \\
\hline Betulaceae & Alnus incana (L.) Moench & $\underline{7}$ & $\mathrm{M}^{3}$ \\
\hline Betulaceae & Alnus viridis (Chaix) DC. & $\underline{6}$ & $\mathrm{M}^{3}$ \\
\hline Rosaceae & Amelanchier ovalis Medicus & $\underline{3}$ & NA \\
\hline Fabaceae & Anagyris foetida $L$. & $\underline{2}$ & NA \\
\hline Fabaceae & Anthyllis barba-jovis L. & $\underline{2}$ & NA \\
\hline Ericaceae & Arbutus unedo L. & $\underline{3}$ & $\mathrm{M}^{5}$ \\
\hline Asteraceae & Artemisia arborescens L. & $\underline{2}$ & NA \\
\hline Fabaceae & Astragalus massiliensis Lam. & $\underline{2}$ & $\underline{\mathrm{NA}}$ \\
\hline Fabaceae & Astragalus sempervirens Lam. & $\underline{4}$ & $\underline{\mathrm{NA}}$ \\
\hline Berberidaceae & Berberis aetnensis Presl & $\underline{2}$ & $\underline{\mathrm{NA}}$ \\
\hline Berberidaceae & Berberis vulgaris $\mathrm{L}$. & $\underline{4}$ & $\underline{1}^{1}$ \\
\hline Betulaceae & Betula nana $\mathrm{L}$. & $\underline{9}$ & NA \\
\hline Betulaceae & Betula pendula Roth & $\underline{5}$ & $\underline{M}^{3}$ \\
\hline Betulaceae & Betula pubescens Ehrh. & $\underline{7}$ & $\mathrm{M}^{3}$ \\
\hline Apiaceae & Bupleurum fruticosum L. & $\underline{3}$ & $\mathrm{M}^{7}$ \\
\hline
\end{tabular}




\begin{tabular}{|c|c|c|c|}
\hline Buxaceae & Buxus balearica Lam. & $\underline{3}$ & $\underline{\mathrm{NA}}$ \\
\hline Buxaceae & Buxus sempervirens L. & $\underline{4}$ & $\underline{1+\mathrm{M}^{3}}$ \\
\hline Fabaceae & $\underline{\text { Calicotome spinosa (L.) Link }}$ & $\underline{2}$ & NA \\
\hline Fabaceae & Calicotome villosa (Poiret) Link & $\underline{2}$ & NA \\
\hline Ericaceae & Calluna vulgaris (L.) Hull & $?$ & $\underline{M^{8}}$ \\
\hline Capparidaceae & Capparis ovata Desf. & $\underline{2}$ & NA \\
\hline Capparidaceae & Capparis spinosa L. & $\underline{2}$ & NA \\
\hline Corylaceae & Carpinus betulus $\mathrm{L}$. & $\underline{7}$ & $\underline{M^{1}}$ \\
\hline Corylaceae & Carpinus orientalis Miller & $\underline{4}$ & $\mathrm{NE}^{3}$ \\
\hline Fagaceae & Castanea sativa Miller & $\underline{5}$ & $M^{3}$ \\
\hline Ulmaceae & Celtis aetnensis (Tornabene) Strobl & $\underline{3}$ & NA \\
\hline Ulmaceae & Celtis australis L. & $\underline{3}$ & $\underline{N A}$ \\
\hline Fabaceae & Ceratonia siliqua L. & 1 & $\underline{M^{1,9}}$ \\
\hline Fabaceae & Cercis siliquastrum L. & $\underline{4}$ & $\underline{\mathrm{NE}}^{3}$ \\
\hline Arecaceae & Chamaerops humilis L. & 1 & $\underline{1^{10}}$ \\
\hline Cistaceae & Cistus albidus L. & $\underline{2}$ & $\underline{M^{1,9}}$ \\
\hline$\underline{\text { Cistaceae }}$ & $\underline{\text { Cistus clusii Dunal }}$ & $\underline{2}$ & $\underline{\mathrm{NA}}$ \\
\hline Cistaceae & Cistus corsicus Loisel. & $\underline{2}$ & NA \\
\hline Cistaceae & Cistus creticus L. & $\underline{2}$ & $\underline{\mathrm{NA}}$ \\
\hline Cistaceae & Cistus crispus L. & $\underline{2}$ & $\underline{\mathrm{NA}}$ \\
\hline Cistaceae & Cistus incanus L. & $\underline{2}$ & $\mathrm{M}^{1}$ \\
\hline Cistaceae & Cistus laurifolius L. & $\underline{2}$ & NA \\
\hline Cistaceae & Cistus monspeliensis L. & $\underline{2}$ & $\underline{M}^{1}$ \\
\hline Cistaceae & Cistus parviflorus Lam. & $\underline{2}$ & $\underline{\mathrm{NA}}$ \\
\hline Cistaceae & Cistus salvifolius L. & $\underline{2}$ & $\underline{M^{6}}$ \\
\hline Ranunculaceae & Clematis alpina (L.) Miller & $\underline{5}$ & $\underline{\mathrm{NA}}$ \\
\hline Ranunculaceae & Clematis cirrhosa L. & $\underline{2}$ & NA \\
\hline Ranunculaceae & Clematis flammula L. & $\underline{3}$ & $\underline{\mathrm{NA}}$ \\
\hline Ranunculaceae & Clematis vitalba $\mathrm{L}$. & $\underline{5}$ & NA \\
\hline Ranunculaceae & Clematis viticella L. & $\underline{4}$ & NA \\
\hline Cneoraceae & Cneorum tricoccon $\mathrm{L}$. & $\underline{2}$ & NA \\
\hline Fabaceae & Colutea arborescens L. & $\underline{3}$ & $\underline{\mathrm{NA}}$ \\
\hline Coriariaceae & Coriaria myrtifolia L. & $\underline{3}$ & NA \\
\hline Cornaceae & Cornus mas L. & $\underline{5}$ & NA \\
\hline Cornaceae & Cornus sanguinea $\mathrm{L}$. & $\underline{6}$ & NA \\
\hline Fabaceae & $\underline{\text { Coronilla emerus } \mathrm{L} .}$ & $\underline{4}$ & NA \\
\hline Fabaceae & Coronilla juncea $\mathrm{L}$. & $\underline{2}$ & NA \\
\hline Fabaceae & Coronilla valentina $\mathrm{L}$. & $\underline{2}$ & $\underline{\mathrm{NA}}$ \\
\hline Corylaceae & Corylus avellana $\mathrm{L}$. & $\underline{6}$ & $\mathrm{NE}^{3}$ \\
\hline$\underline{\text { Anacardiaceae }}$ & Cotinus coggygria Scop. & $\underline{3}$ & $\underline{\mathrm{NA}}$ \\
\hline Rosaceae & $\underline{\text { Cotoneaster integerrimus Medicus }}$ & $\underline{3}$ & NA \\
\hline Rosaceae & Cotoneaster nebrodensis (Guss.) Koch & $\underline{3}$ & NA \\
\hline Rosaceae & $\underline{\text { Crataegus laciniata Ucria }}$ & $\underline{3}$ & $\underline{\mathrm{NA}}$ \\
\hline Rosaceae & Crataegus monogyna Jacq. & $\underline{4}$ & $\underline{M}^{8}$ \\
\hline Rosaceae & Crataegus oxyacantha $\mathrm{L}$. & $\underline{5}$ & $\underline{\mathrm{NA}}$ \\
\hline
\end{tabular}




\begin{tabular}{|c|c|c|c|}
\hline Asclepiadaceae & Cynanchum acutum L. & $\underline{7}$ & $\underline{\mathrm{NA}}$ \\
\hline Fabaceae & Cytisus aeolicus Guss. & $\underline{3}$ & $\underline{\mathrm{NA}}$ \\
\hline Fabaceae & Cytisus scoparius (L.) Link & $\underline{5}$ & $\underline{1}^{6}$ \\
\hline Fabaceae & Cytisus sessilifolius L. & $\underline{5}$ & $\underline{\mathrm{NA}}$ \\
\hline Fabaceae & $\underline{\text { Cytisus villosus Pourret }}$ & $\underline{4}$ & $\underline{N A}$ \\
\hline Thymelaeaceae & Daphne alpina L. & $\underline{3}$ & $\underline{\mathrm{NA}}$ \\
\hline Thymelaeaceae & Daphne gnidium L. & $\underline{3}$ & $\underline{1+M^{8}}$ \\
\hline Thymelaeaceae & Daphne laureola L. & $\underline{5}$ & $\underline{I+M^{11}}$ \\
\hline Thymelaeaceae & Daphne mezereum L. & $\underline{5}$ & NA \\
\hline Thymelaeaceae & Daphne oleoides Schreber & $\underline{2}$ & NA \\
\hline Thymelaeaceae & Daphne sericea Vahl & $\underline{3}$ & $\underline{\mathrm{NA}}$ \\
\hline Elaeagnaceae & Elaeagnus angustifolia L. & $\underline{3}$ & $\mathrm{NE}^{2}$ \\
\hline Empetraceae & Empetrum hermaphroditum Hagerup & $\underline{4}$ & NA \\
\hline Ephedraceae & Ephedra distachya L. & $\underline{3}$ & $\underline{\mathrm{NA}}$ \\
\hline Ephedraceae & Ephedra fragilis Desf. & $\underline{3}$ & $\underline{\mathrm{NA}}$ \\
\hline Ephedraceae & Ephedra helvetica C.A. Meyer & $\underline{3}$ & $\underline{N A}$ \\
\hline Ephedraceae & Ephedra major Host & $\underline{3}$ & $\underline{\mathrm{NA}}$ \\
\hline Ericaceae & Erica arborea L. & $\underline{4}$ & $\underline{1+M^{3}}$ \\
\hline Ericaceae & Erica carnea L. & $\underline{3}$ & $\mathrm{NE}^{2}$ \\
\hline Ericaceae & Erica cinerea L. & $\underline{3}$ & $\mathrm{M}^{8}$ \\
\hline Ericaceae & Erica multiflora L. & $\underline{3}$ & $\underline{1}^{5}$ \\
\hline Ericaceae & Erica scoparia L. & $\underline{3}$ & $\mathrm{NE}^{3}$ \\
\hline Ericaceae & Erica sicula Guss. & $\underline{2}$ & $\underline{\mathrm{NA}}$ \\
\hline Ericaceae & Erica terminalis Salisb. & $\underline{2}$ & NA \\
\hline Celastraceae & Euonymus europaeus L. & $\underline{5}$ & $\underline{\mathrm{NA}}$ \\
\hline Celastraceae & Euonymus latifolius (L.) Miller & $\underline{5}$ & NA \\
\hline Celastraceae & Euonymus verrucosus Scop. & $\underline{5}$ & NA \\
\hline Euphorbiaceae & Euphorbia dendroides L. & $\underline{2}$ & NA \\
\hline Fagaceae & Fagus sylvatica L. & $\underline{5}$ & $\underline{M^{3}}$ \\
\hline Moraceae & Ficus carica L. & $\underline{7}$ & $\underline{1}^{9}$ \\
\hline Rhamnaceae & Frangula alnus Miller & $\underline{7}$ & $1+M^{8}$ \\
\hline Rhamnaceae & Frangula rupestris (Scop.) Schur & $\underline{3}$ & NA \\
\hline Oleaceae & Fraxinus excelsior $\mathrm{L}$. & $\underline{7}$ & $\mathrm{NE}^{3}$ \\
\hline Oleaceae & Fraxinus ornus L. & $\underline{4}$ & $\mathrm{NE}^{3}$ \\
\hline Oleaceae & Fraxinus oxycarpa Bieb. & $\underline{7}$ & $\underline{\mathrm{NA}}$ \\
\hline Fabaceae & Genista acanthoclada DC. & $\underline{2}$ & $\underline{\mathrm{NA}}$ \\
\hline Fabaceae & Genista aetnensis (Biv.) DC. & $\underline{3}$ & $\underline{\mathrm{NA}}$ \\
\hline Fabaceae & Genista anglica L. & $\underline{3}$ & $\underline{I^{11}}$ \\
\hline Fabaceae & Genista aspalathoides Lam. & $\underline{2}$ & $\underline{\mathrm{NA}}$ \\
\hline Fabaceae & Genista cinerea (Vill.) DC. & $\underline{3}$ & $\underline{\mathrm{NA}}$ \\
\hline Fabaceae & Genista corsica (Loisel.) DC. & $\underline{2}$ & $\underline{\mathrm{NA}}$ \\
\hline Fabaceae & Genista ephedroides DC. & $\underline{2}$ & $\underline{\mathrm{NA}}$ \\
\hline Fabaceae & Genista morisii Colla & $\underline{2}$ & NA \\
\hline Fabaceae & Genista salzmannii DC. & $\underline{2}$ & $\underline{\mathrm{NA}}$ \\
\hline Cistaceae & Halimium halimifolium (L.) Willk. & $\underline{2}$ & $\underline{\mathrm{NA}}$ \\
\hline
\end{tabular}




\begin{tabular}{|c|c|c|c|}
\hline Araliaceae & Hedera helix L. & $\underline{5}$ & $\mathrm{NE}^{4}$ \\
\hline Elaeagnaceae & Hippophae rhamnoides L. & $\underline{7}$ & $\mathrm{M}^{1}$ \\
\hline Cannabaceae & Humulus lupulus L. & $\underline{8}$ & $\mathrm{NE}^{2}$ \\
\hline Aquifoliaceae & llex aquifolium $\mathrm{L}$. & $\underline{5}$ & $\overline{\mathrm{NE}^{3}}$ \\
\hline Cupressaceae & Juniperus communis L. & $\underline{4}$ & $\underline{M}^{3}$ \\
\hline Cupressaceae & Juniperus oxycedrus L. & $\underline{3}$ & $M^{3}$ \\
\hline Cupressaceae & Juniperus phoenicea L. & $\underline{2}$ & $\mathrm{M}^{12}$ \\
\hline Cupressaceae & Juniperus sabina L. & $\underline{3}$ & NA \\
\hline Cupressaceae & $\underline{\text { Juniperus thurifera L. }}$ & $\underline{3}$ & $\underline{N A}$ \\
\hline Chenopodiaceae & Kochia prostrata (L.) Schrader & $\underline{3}$ & NA \\
\hline Fabaceae & Laburnum alpinum (Miller) B. et Presl & $\underline{6}$ & $\underline{\mathrm{NA}}$ \\
\hline Fabaceae & Laburnum anagyroides Medicus & $\underline{5}$ & $\underline{I+M^{11}}$ \\
\hline Pinaceae & Larix decidua Miller & $\underline{4}$ & $M^{3}$ \\
\hline Lauraceae & Laurus nobilis L. & $\underline{7}$ & $\underline{M}^{21}$ \\
\hline Lamiaceae & Lavandula angustifolia Miller & $\underline{3}$ & $\underline{N A}$ \\
\hline Lamiaceae & Lavandula latifolia Medicus & $\underline{3}$ & NA \\
\hline Lamiaceae & $\underline{\text { Lavandula multifida L. }}$ & $\underline{3}$ & $\underline{\mathrm{NA}}$ \\
\hline Lamiaceae & Lavandula stoechas L. & $\underline{2}$ & $\mathrm{M}^{6}$ \\
\hline Malvaceae & Lavatera agrigentina Tineo & $\underline{2}$ & $\underline{N A}$ \\
\hline Malvaceae & $\underline{\text { Lavatera maritima Gouan }}$ & $\underline{2}$ & $\underline{\mathrm{NA}}$ \\
\hline Malvaceae & Lavatera olbia L. & $\underline{2}$ & NA \\
\hline Malvaceae & Lavatera triloba $\mathrm{L}$. & $\underline{2}$ & NA \\
\hline Fabaceae & Lembotropis nigricans (L.) Griseb. & $\underline{4}$ & NA \\
\hline Oleaceae & Ligustrum vulgare $\mathrm{L}$. & $?$ & $\mathrm{NE}^{2}$ \\
\hline Caprifoliaceae & Lonicera alpigena L. & $\underline{6}$ & $\underline{\mathrm{NA}}$ \\
\hline Caprifoliaceae & Lonicera caprifolium L. & $\underline{6}$ & NA \\
\hline Caprifoliaceae & Lonicera coerulea L. & $\underline{8}$ & NA \\
\hline$\underline{\text { Caprifoliaceae }}$ & Lonicera etrusca Santi & $\underline{3}$ & $\underline{N A}$ \\
\hline$\underline{\text { Caprifoliaceae }}$ & Lonicera implexa Aiton & $\underline{3}$ & $\underline{\mathrm{NA}}$ \\
\hline Caprifoliaceae & Lonicera nigra L. & $\underline{5}$ & NA \\
\hline$\underline{\text { Caprifoliaceae }}$ & Lonicera peryclymenum L. & $\underline{?}$ & NA \\
\hline$\underline{\text { Caprifoliaceae }}$ & Lonicera stabiana Pasquale & $\underline{2}$ & $\underline{\mathrm{NA}}$ \\
\hline Caprifoliaceae & Lonicera xylosteum L. & $\underline{5}$ & $\underline{\mathrm{NA}}$ \\
\hline Rosaceae & Malus domestica Borkh. & $\underline{5}$ & $\mathrm{NE}^{3}$ \\
\hline Rosaceae & Malus florentina (Zuccagni) Schneider & $\underline{5}$ & $\underline{N A}$ \\
\hline Rosaceae & Malus sylvestris Miller & $\underline{5}$ & $\underline{\mathrm{NA}}$ \\
\hline Rosaceae & Mespilus germanica L. & $\underline{4}$ & $\underline{\mathrm{NA}}$ \\
\hline Myrtaceae & Myrtus communis L. & $\underline{2}$ & $\underline{I+M^{13}}$ \\
\hline Apocynaceae & Nerium oleander $\mathrm{L}$. & $\underline{7}$ & $\mathrm{NE}^{6}$ \\
\hline Oleaceae & Olea europaea L. var. sylvestris Brot. & 1 & $\mathrm{M}^{1,9}$ \\
\hline Corylaceae & Ostrya carpinifolia Scop. & $\underline{4}$ & $\underline{N E}^{3}$ \\
\hline Santalaceae & Osyris alba L. & $\underline{3}$ & NA \\
\hline Rhamnaceae & Paliurus spina-christi Miller & $\underline{3}$ & $\underline{\mathrm{NA}}$ \\
\hline$\underline{\text { Asclepiadaceae }}$ & Periploca graeca L. & $\underline{7}$ & $\underline{N A}$ \\
\hline Asclepiadaceae & Periploca laevigata Aiton & $\underline{2}$ & NA \\
\hline
\end{tabular}




\begin{tabular}{|c|c|c|c|}
\hline Oleaceae & Phillyrea angustifolia L. & $\underline{2}$ & $\underline{M^{12}}$ \\
\hline Oleaceae & Phillyrea latifolia L. & $\underline{4}$ & $\mathrm{M}^{3}$ \\
\hline Lamiaceae & Phlomis ferruginea Ten. & $\underline{3}$ & NA \\
\hline Lamiaceae & Phlomis fruticosa L. & $\underline{3}$ & $\underline{M}^{1}$ \\
\hline Pinaceae & Picea excelsa (Lam.) Link & $\underline{4}$ & $\underline{M}^{3}$ \\
\hline Pinaceae & Pinus cembra L. & $\underline{5}$ & $\underline{M^{3}}$ \\
\hline Pinaceae & Pinus halepensis Miller & $\underline{2}$ & $M^{9}$ \\
\hline Pinaceae & Pinus laricio Poiret & $\underline{3}$ & $\underline{M}^{1}$ \\
\hline Pinaceae & Pinus leucodermis Antoine & $\underline{2}$ & $\mathrm{M}^{3}$ \\
\hline Pinaceae & Pinus mugo Turra & $?$ & $\mathrm{M}^{3}$ \\
\hline Pinaceae & Pinus nigra Arnold & $\underline{2}$ & $\underline{M}^{3}$ \\
\hline Pinaceae & Pinus pinaster Aiton & $\underline{2}$ & $\underline{M}^{8}$ \\
\hline Pinaceae & Pinus pinea L. & $\underline{2}$ & $\mathrm{M}^{3}$ \\
\hline Pinaceae & Pinus sylvestris $\mathrm{L}$. & $\underline{?}$ & $\underline{M}^{3}$ \\
\hline Pinaceae & $\underline{\text { Pinus uncinata Miller }}$ & $\underline{5}$ & $\underline{M}^{3}$ \\
\hline Anacardiaceae & Pistacia lentiscus L. & $\underline{2}$ & $\underline{M}^{3}$ \\
\hline Anacardiaceae & Pistacia terebinthus L. & $\underline{2}$ & $\underline{\mathrm{NE}}^{1}$ \\
\hline Platanaceae & Platanus orientalis $L$. & $\underline{7}$ & $\underline{1}^{3}$ \\
\hline Salicaceae & Populus alba L. & $\underline{7}$ & $\underline{1}^{3}$ \\
\hline Salicaceae & Populus canescens (Aiton) Sm. & $\underline{7}$ & $1^{3}$ \\
\hline Salicaceae & Populus nigra L. & $\underline{8}$ & $\underline{1}^{3}$ \\
\hline Salicaceae & Populus tremula L. & $\underline{5}$ & $\underline{1}^{3}$ \\
\hline Rosaceae & Prunus avium $\mathrm{L}$. & $\underline{5}$ & $\mathrm{NE}^{3}$ \\
\hline Rosaceae & Prunus brigantina Vill. & $\underline{5}$ & NA \\
\hline Rosaceae & Prunus cerasifera Ehrh. & $\underline{5}$ & $\underline{\mathrm{NE}}^{14}$ \\
\hline Rosaceae & Prunus cocomilia Ten. & $\underline{5}$ & NA \\
\hline Rosaceae & Prunus fruticosa Pallas & $\underline{3}$ & NA \\
\hline Rosaceae & Prunus mahaleb L. & $\underline{3}$ & $\underline{N A}$ \\
\hline Rosaceae & Prunus padus L. & $\underline{8}$ & $\mathrm{NE}^{3}$ \\
\hline Rosaceae & Prunus prostrata Labill. & $\underline{2}$ & NA \\
\hline Rosaceae & Prunus spinosa L. & $\underline{?}$ & $\underline{M}^{11}$ \\
\hline Rosaceae & Prunus webbii (Spach) Vierh. & $\underline{2}$ & NA \\
\hline Rubiaceae & Putoria calabrica (L.fil.) Pers. & $\underline{2}$ & $\underline{\mathrm{NA}}$ \\
\hline Rosaceae & Pyracantha coccinea Roemer & $\underline{3}$ & $\mathrm{NE}^{14}$ \\
\hline Rosaceae & Pyrus amygdaliformis Vill. & $\underline{4}$ & $\underline{N A}$ \\
\hline Rosaceae & Pyrus pyraster Burgsd. & $\underline{5}$ & $\mathrm{M}^{1}$ \\
\hline Fagaceae & Quercus cerris L. & $\underline{5}$ & $\mathrm{NE}^{15}$ \\
\hline Fagaceae & Quercus coccifera L. & $\underline{3}$ & $\underline{M}^{3}$ \\
\hline Fagaceae & Quercus frainetto Ten. & $\underline{6}$ & $\underline{1}^{3}$ \\
\hline Fagaceae & Quercus ilex L. & $\underline{3}$ & $\underline{M^{3}}$ \\
\hline Fagaceae & Quercus macrolepis Kotschy & $\underline{3}$ & $\underline{M}^{3}$ \\
\hline Fagaceae & Quercus petraea (Mattuschka) Liebl. & $\underline{5}$ & $1+M^{3}$ \\
\hline Fagaceae & Quercus pubescens Willd. & $\underline{3}$ & $\underline{1}^{3}$ \\
\hline Fagaceae & Quercus pyrenaica Willd. & $\underline{5}$ & $\underline{1+M^{8}}$ \\
\hline Fagaceae & Quercus robur L. & $\underline{7}$ & $\underline{1}^{1}$ \\
\hline
\end{tabular}




\begin{tabular}{|c|c|c|c|}
\hline Fagaceae & Quercus suber $\mathrm{L}$. & $\underline{3}$ & $\underline{M^{9}}$ \\
\hline Fagaceae & Quercus trojana Webb & $\underline{3}$ & $\mathrm{NE}^{15}$ \\
\hline Fabaceae & Retama raetam (Forsskal) Webb et Berth. & $\underline{1}$ & NA \\
\hline Rhamnaceae & Rhamnus alaternus L. & $\underline{3}$ & $\underline{\mathrm{NE}}^{16}$ \\
\hline$\underline{\text { Rhamnaceae }}$ & $\underline{\text { Rhamnus alpinus L. }}$ & $\underline{5}$ & $\underline{\mathrm{NA}}$ \\
\hline Rhamnaceae & Rhamnus catharticus L. & $\underline{4}$ & $\underline{1^{11}}$ \\
\hline Rhamnaceae & Rhamnus glaucophyllus Sommier & $\underline{4}$ & NA \\
\hline Rhamnaceae & Rhamnus lojaconoi Raimondo & $\underline{4}$ & NA \\
\hline$\underline{\text { Rhamnaceae }}$ & Rhamnus oleoides L. & $\underline{2}$ & $\underline{\mathrm{NA}}$ \\
\hline Rhamnaceae & Rhamnus persicifolius Moris & $\underline{3}$ & NA \\
\hline Rhamnaceae & Rhamnus pumilus Turra & $\underline{2}$ & NA \\
\hline Rhamnaceae & Rhamnus saxatilis Jacq. & $\underline{3}$ & NA \\
\hline Ericaceae & Rhododendron ferrugineum $\mathrm{L}$. & $\underline{6}$ & $\underline{\mathrm{NA}}$ \\
\hline Ericaceae & Rhododendron hirsutum L. & $\underline{4}$ & NA \\
\hline Anacardiaceae & Rhus pentaphylla (Jacq.) Desf. & $\underline{3}$ & $\underline{\mathrm{NA}}$ \\
\hline Anacardiaceae & Rhus tripartita (Ucria) Grande & $\underline{3}$ & NA \\
\hline Saxifragaceae & Ribes alpinum L. & $\underline{?}$ & $\underline{\mathrm{NA}}$ \\
\hline Saxifragaceae & Ribes multiflorum Kit. & $\underline{6}$ & $\underline{M}^{1}$ \\
\hline Saxifragaceae & Ribes nigrum L. & $\underline{6}$ & $\underline{\mathrm{NE}}^{4}$ \\
\hline Saxifragaceae & Ribes petraeum Wulfen & $\underline{4}$ & NA \\
\hline Saxifragaceae & Ribes rubrum L. & $\underline{8}$ & $\underline{\mathrm{NA}}$ \\
\hline Saxifragaceae & Ribes sardoum Martelli & $\underline{3}$ & NA \\
\hline Saxifragaceae & Ribes uva-crispa L. & $\underline{?}$ & NA \\
\hline Rosaceae & Rosa agrestis Savi & $\underline{3}$ & NA \\
\hline Rosaceae & Rosa arvensis Hudson & $\underline{5}$ & $\underline{\mathrm{NA}}$ \\
\hline Rosaceae & Rosa canina L. & $\underline{4}$ & $\mathrm{M}^{1,17}$ \\
\hline Rosaceae & Rosa gallica L. & $\underline{4}$ & $\underline{M^{1}}$ \\
\hline Rosaceae & Rosa micrantha Sm. & $\underline{3}$ & $\underline{\mathrm{NA}}$ \\
\hline Rosaceae & Rosa pendulina $\mathrm{L}$. & $\underline{5}$ & $\underline{\mathrm{NA}}$ \\
\hline Rosaceae & Rosa pouzinii Tratt. & $\underline{3}$ & NA \\
\hline Rosaceae & Rosa sempervirens $\mathrm{L}$. & $\underline{3}$ & NA \\
\hline Lamiaceae & Rosmarinus officinalis $\mathrm{L}$. & $\underline{2}$ & $\mathrm{M}^{1,13}$ \\
\hline Rosaceae & Rubus caesius L. & $\underline{7}$ & $\mathrm{M}^{11}$ \\
\hline Rosaceae & Rubus canescens DC. & $\underline{4}$ & NA \\
\hline Rosaceae & Rubus hirtus W. et K. & $\underline{4}$ & NA \\
\hline Rosaceae & Rubus idaeus L. & $\underline{5}$ & $\mathrm{NE}^{4}$ \\
\hline Rosaceae & Rubus ulmifolius Schott & $\underline{4}$ & $\underline{M}^{8}$ \\
\hline Salicaceae & Salix alba L. & $\underline{8}$ & $\underline{1}^{1}$ \\
\hline Salicaceae & Salix alpina Scop. & $\underline{3}$ & $\underline{1}^{1}$ \\
\hline Salicaceae & Salix apennina Skvortsov & $\underline{7}$ & $\underline{1}^{1}$ \\
\hline Salicaceae & Salix atrocinerea Brot. & $\underline{7}$ & $\underline{1}^{1}$ \\
\hline Salicaceae & Salix aurita L. & $\underline{8}$ & $\underline{1}^{1}$ \\
\hline Salicaceae & Salix breviserrata Flod. & $\underline{3}$ & NA \\
\hline Salicaceae & $\underline{\text { Salix caesia Vill. }}$ & $\underline{4}$ & $\underline{\mathrm{NA}}$ \\
\hline Salicaceae & Salix caprea L. & $\underline{6}$ & $\underline{1}^{3}$ \\
\hline
\end{tabular}




\begin{tabular}{|c|c|c|c|}
\hline Salicaceae & Salix cinerea $\mathrm{L}$. & $\underline{9}$ & $\underline{1}^{1}$ \\
\hline Salicaceae & Salix crataegifolia Bertol. & $\underline{6}$ & NA \\
\hline Salicaceae & Salix daphnoides Vill. & $\underline{4}$ & NA \\
\hline Salicaceae & Salix eleagnos Scop. & $\underline{7}$ & $\underline{1}^{1}$ \\
\hline Salicaceae & $\underline{\text { Salix foetida Schleicher }}$ & $\underline{4}$ & $\underline{N A}$ \\
\hline Salicaceae & Salix fragilis $L$. & $\underline{8}$ & $\underline{1}^{1}$ \\
\hline Salicaceae & Salix glabra Scop. & $\underline{4}$ & $\underline{1}^{1}$ \\
\hline Salicaceae & Salix glaucosericea Flod. & $\underline{3}$ & NA \\
\hline Salicaceae & Salix hastata L. & $\underline{6}$ & NA \\
\hline Salicaceae & Salix hegetschweileri Heer & $\underline{3}$ & NA \\
\hline Salicaceae & Salix helvetica Vill. & $\underline{4}$ & NA \\
\hline Salicaceae & Salix herbacea L. & $\underline{7}$ & $\underline{1}^{1}$ \\
\hline Salicaceae & $\underline{\text { Salix myrsinifolia Salisb. }}$ & $\underline{7}$ & NA \\
\hline Salicaceae & Salix pentandra L. & $\underline{8}$ & $\underline{1}^{1}$ \\
\hline Salicaceae & Salix purpurea L. & $?$ & $\underline{1}^{1}$ \\
\hline Salicaceae & Salix repens L. & $\underline{8}$ & $\underline{1}^{1}$ \\
\hline Salicaceae & Salix reticulata L. & $\underline{6}$ & $\underline{1}^{1}$ \\
\hline Salicaceae & Salix retusa L. & $\underline{6}$ & NA \\
\hline Salicaceae & Salix serpillyfolia Scop. & $\underline{4}$ & NA \\
\hline Salicaceae & Salix triandra $\mathrm{L}$. & $\underline{8}$ & $\underline{1}^{1}$ \\
\hline Salicaceae & Salix viminalis L. & $\underline{8}$ & $\underline{1}^{19}$ \\
\hline Salicaceae & Salix waldsteiniana Willd. & $\underline{6}$ & NA \\
\hline Caprifoliaceae & Sambucus nigra L. & $\underline{5}$ & $\mathrm{NE}^{11}$ \\
\hline Caprifoliaceae & Sambucus racemosa L. & $\underline{5}$ & $\mathrm{NE}^{11}$ \\
\hline Rosaceae & Sarcopoterium spinosum (L.) Spach & $\underline{2}$ & NA \\
\hline Smilacaceae & Smilax aspera L. & $\underline{3}$ & $\overline{\mathrm{NA}}$ \\
\hline Rosaceae & Sorbus aria (L.) Crantz & $\underline{4}$ & $\mathrm{NE}^{3}$ \\
\hline Rosaceae & Sorbus aucuparia L. & $\underline{5}$ & $\mathrm{NE}^{3}$ \\
\hline Rosaceae & Sorbus chamaemespilus (L.) Crantz & $\underline{4}$ & NA \\
\hline Rosaceae & $\underline{\text { Sorbus domestica L. }}$ & $\underline{3}$ & $\mathrm{NE}^{3}$ \\
\hline Rosaceae & Sorbus torminalis (L.) Crantz & $\underline{4}$ & $\mathrm{NE}^{3}$ \\
\hline Fabaceae & Spartium junceum L. & $\underline{4}$ & $1^{9}$ \\
\hline Staphyleaceae & Staphylea pinnata L. & $\underline{5}$ & NA \\
\hline Styracaceae & Styrax officinalis L. & $\underline{4}$ & $\mathrm{NE}^{2}$ \\
\hline Tamaricaceae & Tamarix africana Poiret & $\underline{6}$ & $\mathrm{NE}^{6}$ \\
\hline Tamaricaceae & Tamarix canariensis Willd. & $\underline{6}$ & NA \\
\hline Tamaricaceae & Tamarix dalmatica Baum & $\underline{6}$ & $\underline{N A}$ \\
\hline Tamaricaceae & Tamarix gallica L. & $\underline{6}$ & $\mathrm{NE}^{21}$ \\
\hline Taxaceae & Taxus baccata L. & $\underline{5}$ & $\mathrm{M}^{21}$ \\
\hline Fabaceae & Teline monspessulana (L.) Koch & $\underline{4}$ & NA \\
\hline Lamiaceae & $\underline{\text { Teucrium fruticans } \mathrm{L} .}$ & $\underline{2}$ & NA \\
\hline Thymelaeaceae & Thymelaea dioica (Gouan) All. & $\underline{3}$ & NA \\
\hline Thymelaeaceae & Thymelaea hirsuta (L.) Endl. & $\underline{2}$ & NA \\
\hline Thymelaeaceae & Thymelaea tartonraira (L.) All. & $\underline{2}$ & $\underline{\mathrm{NA}}$ \\
\hline Lamiaceae & Thymus capitatus (L.) Hofmgg. et Lk. & $\underline{2}$ & $\underline{\mathrm{NA}}$ \\
\hline
\end{tabular}




\begin{tabular}{|c|c|c|c|}
\hline$\underline{\text { Tiliaceae }}$ & Tilia cordata Miller & $\stackrel{?}{?}$ & $\mathrm{NE}^{3}$ \\
\hline Tiliaceae & Tilia platyphyllos Scop. & $\underline{6}$ & $\underline{I^{11}}$ \\
\hline Fabaceae & Ulex europaeus $\mathrm{L}$. & $\underline{5}$ & $I+M^{11}$ \\
\hline$\underline{\text { Ulmaceae }}$ & $\underline{\text { Ulmus canescens Melville }}$ & $\underline{3}$ & $\underline{\mathrm{NA}}$ \\
\hline$\underline{\text { Ulmaceae }}$ & $\underline{\text { Ulmus glabra Hudson }}$ & $\underline{6}$ & $\underline{N E}^{3}$ \\
\hline$\underline{\text { Ulmaceae }}$ & Ulmus minor Miller & $\underline{7}$ & $\mathrm{NE}^{3}$ \\
\hline Ericaceae & Vaccinium gaultherioides Bigelow & $\underline{5}$ & NA \\
\hline Ericaceae & Vaccinium microcarpum (Turcz.) H. Fil. & $\underline{9}$ & $\underline{\mathrm{NA}}$ \\
\hline Ericaceae & Vaccinium myrtillus L. & $\underline{?}$ & $\mathrm{NE}^{19}$ \\
\hline Ericaceae & Vaccinium oxycoccos L. & $\underline{9}$ & $\underline{\mathrm{NA}}$ \\
\hline Ericaceae & Vaccinium uliginosum L. & $\underline{9}$ & $\underline{\mathrm{NE}}^{20}$ \\
\hline Ericaceae & Vaccinium vitis-idaea $\mathrm{L}$. & $\underline{4}$ & $\underline{\mathrm{NE}^{19}}$ \\
\hline Caprifoliaceae & Viburnum lantana L. & $\underline{4}$ & $\underline{\mathrm{NA}}$ \\
\hline$\underline{\text { Caprifoliaceae }}$ & Viburnum opulus L. & $\underline{7}$ & $\underline{\mathrm{NE}^{11}}$ \\
\hline Caprifoliaceae & Viburnum tinus L. & $\underline{4}$ & $\underline{\mathrm{NA}}$ \\
\hline Apocynaceae & Vinca difformis Pourret & $\underline{3}$ & $\underline{\mathrm{NA}}$ \\
\hline Apocynaceae & Vinca major L. & $\underline{4}$ & $\underline{\mathrm{NA}}$ \\
\hline Apocynaceae & Vinca minor $\mathrm{L}$. & $\underline{5}$ & $\underline{\mathrm{NA}}$ \\
\hline Apocynaceae & Vinca sardoa (Stearn) Pign. & $\underline{3}$ & NA \\
\hline$\underline{\text { Verbenaceae }}$ & Vitex agnus-castus $L$. & $\underline{7}$ & $\underline{M^{3}}$ \\
\hline$\underline{\text { Vitaceae }}$ & Vitis vinifera L. & $\underline{7}$ & $\underline{M}^{8}$ \\
\hline$\underline{\text { Rhamnaceae }}$ & Ziziphus lotus (L.) Lam. & 1 & $\underline{\mathrm{NA}}$ \\
\hline
\end{tabular}

Common exotic woody plants

\begin{tabular}{|l|l|c|c|}
\hline Cupressaceae & Cupressus sempervirens L. & $\underline{3}$ & $\underline{\mathrm{M}^{1}}$ \\
\hline Platanaceae & Platanus x acerifolia (Aiton) Wild. & $\underline{8}$ & $\underline{\mathrm{I}^{1}}$ \\
\hline Salicaceae & Populus canadensis L. & $\underline{7}$ & $\underline{\mathrm{I}^{1}}$ \\
\hline$\underline{\text { Fabaceae }}$ & $\underline{\text { Robinia pseudoacacia L. }}$ & $\underline{4}$ & $\underline{\mathrm{I}^{1}}$ \\
\hline Oleaceae & $\underline{\text { Syringa vulgaris L. }}$ & $\underline{5}$ & $\underline{\mathrm{NE}^{1}}$ \\
\hline
\end{tabular}

${ }^{1}$ This study

${ }^{2}$ Rasmussen, R. (1978) Isoprene plant species list. Special Report of the Air Pollution Research Section, Washington State University, Pullman.

${ }^{3}$ Steinbrecher, R., Smiatek, G., Köble, R., Seufert, G., Theloke, J., Hauff, K., Ciccioli, P., Vautard, R. \& Curci, G. (2009) Intra- and inter-annual variability of VOC emissions from natural and semi-natural vegetation in Europe and neighbouring countries. Atmospheric Environment, 43, 1380-1391.

${ }^{4}$ Hewitt, C. \& Street, R. (1992) A qualitative assessment of the emission of non-methane hydrocarbon compounds from the biosphere to the atmosphere in the UK: present knowledge and uncertainties. Atmospheric Environment, 26, 3069-3077.

${ }^{5}$ Owen, S., Boissard, C., Street, R., Duckham, S., Csiky, O. \& Hewitt, C. (1997) Screening of 18 Mediterranean plant species for volatile organic compound emissions. Atmospheric Environment, 31, 101-117.

${ }^{6}$ Owen., S. (1998) PhD Thesis. Lancaster University, Lancaster.

${ }^{7}$ Llusia, J. \& Peñuelas, J. (2000) Seasonal patterns of terpene content and emission from seven Mediterranean woody species in field conditions. American Journal of Botany, 87, 133-140. 
${ }^{8}$ Pio, C., Nunes, T. \& Brito, S. (1993) Volatile hydrocarbon emissions from common and native species of vegetation in Portugal. In: Slanina, J. et al. (Eds.), Proceedings of Joint Workshop of CEC/BIATEX of EUROTRAC, General Assessment of Biogenic Emissions and Deposition of Nitrogen Compounds, Sulphur Compounds and Oxidants in Europe. Air Pollution Research Report 47, Aveiro, Portugal, pp. 291-298. ISBN 2-87263-095-3.

${ }^{9}$ Bracho-Nunez, A. (2008) Screening plant species for regional and global VOC budgets: a multimethod experiment to determine plant-specific emission factors. Scientific Report of a VOCBAS Exchange grant.

${ }^{10}$ Baraldi, R., Rapparini, F., Facini, O., Spano, D. \& Duce, P. (2005) Isoprenoid emissions and physiological activities of Mediterranean macchia vegetation under field conditions. Journal of Mediterranean Ecology, 6, 1, 3-9.

${ }^{11}$ Stewart, H., Hewitt, N., Bunce, H., Steinbrecher, R., Smiatek, G. \& Schoenemeyer, T. (2003) A highly spatially and temporally resolved inventory for biogenic isoprene and monoterpene emissions: Model description and application to Great Britain. Journal of Geophysical Research, 108, 4644.

12 Seufert, G., Bartzis, J., Bomboi, T., Ciccioli, P., Cieslik, S., Dlugi, R., Foster, P., Hewitt, N., Kesselmeier, J., Kotzias, D., Lenz, R., Manes, F., Perez Pastor, R., Steinbrecher, R., Torres, L., Valentini, R. \& Versino, B. (1997) An overview of the Castelporziano experiments. Atmospheric Environment, 31, 5-17.

${ }^{13}$ Hansen, U., Van Eijk, J., Bertin, N., Staudt, M., Kotzias, D., Seufert, G., Fugit, J., Torres, L., Cecinato, A., Brancaleoni, E., Ciccioli, P. \& Bomboi, T. (1997) Biogenic emissions and $\mathrm{CO}_{2}$ gas exchange investigated on four Mediterranean shrubs. Atmospheric Environment, 31, 157-167.

${ }^{14}$ Benjamin, M. \& Sudol, M. (1996) Low emitting urban forest: A taxonomic methodology for assigning isoprene and monoterpene emission rate. Atmospheric Environment, 30, 1437- 1452.

${ }^{15}$ Csiky, O \& Seufert, G. (1999) Terpenoid emissions of Mediterranean oaks and their relation to taxonomy. Ecological Applications, 9, 1138-1146.

${ }^{16}$ Affek, H. \& Yakir, D. (2002) Protection by Isoprene against Singlet Oxygen in Leaves. Plant Physiology, 129, 269-277.

${ }^{17}$ Bergougnoux,V., Caissard, J., Jullien, F., Magnard, J., Scalliet, G., Cock, J., Hugueney, P. \& Baudino, S. (2007) Both the adaxial and abaxial epidermal layers of the rose petal emit volatile scent compounds. Planta, 226, 853-866.

18 Olofsson, M., Ek-Olausson, B., Jensen, N., Langer, S. \& Ljungstr $\square$ m, E. (2005) The flux of isoprene from a willow plantation and the effect on local air quality. Atmospheric Environment, 39, 2061-2070.

${ }^{19}$ Isidorov, V., Zenkevich, I. \& Ioffe, B. (1985) Volatile organic compounds in the atmosphere of forests. Atmospheric Environment, 19, 1-8.

${ }^{20}$ Drewitt, G., Curren, K., Steyn, D., Gillespie, T. \& Niki, H. (1998) Measurement of biogenic hydrocarbon emissions from vegetation in the lower fraser valley; British Columbia. Atmospheric Environment, 32, 4357-3466.

${ }^{21}$ Noe, S., Peñuelas, J. \& Niinemets, Ü., (2008) Monoterpene emissions from ornamental trees in urban areas: a case study of Barcelona, Spain. Plant Biology, 10, 163-169. 
Appendix S2. List of references used to reconstruct the phylogenetic relationships of species.

Alice, L.A. \& Campbell, C.S. (1999). Phylogeny of Rubus (rosaceae) based on nuclear ribosomal DNA internal transcribed spacer region sequences. American Journal of Botany, 86, 81-97.

Bellarosa, R., Simeone, M.C., Papini, A. \& Schirone B. (2005). Utility of ITS sequence data for phylogenetic reconstruction of Italian Quercus spp. Molecular Phylogenetics and Evolution, 34, 355-370.

Bolmgren, K. \& Oxelman, B. (2004). Generic limits in Rhamnus L. s.l. (Rhamnaceae) inferred from nuclear and chloroplast DNA sequence phylogenies. Taxon, 53, 383-390.

Bortiri, E., Oh, S.-H., Jiang, J., Baggett, S., Granger, A., Weeks, C., Buckingham, M., Potter, D. \& Parfitt, D.E. (2001). Phylogeny and Systematics of Prunus (Rosaceae) as Determined by Sequence Analysis of ITS and the Chloroplast trnL-trnF Spacer DNA. Systematic Botany, 26, 797-807.

Chen, Z. D., Manchester, S.R. \& Sun HY. (1999). Phylogeny and evolution of the Betulaceae as inferred from DNA sequences, morphology, and paleobotany. American Journal of Botany, 86, $1168-1181$.

Eckert, A.J. \& Hall, B.D. (2006). Phylogeny, historical biogeography, and patterns of diversification for Pinus (Pinaceae): phylogenetic tests of fossil-based hypotheses. Molecular Phylogenetics and Evolution. 40, 166-182.

Guzmán, B. \& Vargas, P. (2005). Systematics, character evolution, and biogeography of Cistus L. (Cistaceae) based on ITS, trnL-trnF, and matK sequences. Molecular Phylogenetics and Evolution. 37, 644-660.

Hamzeh, M. \& S. Dayanandan. 2004. Phylogeny of Populus (Salicaceae) based on nucleotide sequences of chloroplast trnT-trnF region and nuclear rDNA. American Journal of Botany, 91, $1398-1408$.

Leskinen, E. \& Alström-Rapaport, C. (1999). Molecular phylogeny of Salicaceae and closely related Flacourtiaceae: evidence from 5.8 S, ITS 1 and ITS 2 of the rDNA. Plant Systematics and Evolution, 215, 209-227.

Li, J., Yue, J. \& Shoup, S. Phylogenetics of Acer (Aceroideae, Sapindaceae) based on nucleotide sequences of two chloroplast non-coding regions. Harvard Papers in Botany, 11, 101-115.

McGuire, A.F. \& Kron, K.A. (2005). Phylogenetic relationships of European and African ericas. International Journal of Plant Sciences, 166, 311-318.

Navarro, E., Bousquet, J., Moiroud, A., Munive, A., Piou, D. \& Normand, P. (2003). Molecular phylogeny of Alnus (Betulaceae), inferred from nuclear ribosomal DNA ITS sequences. Plant and Soil, 254, 207-217.

Potter, D., Eriksson, T., Evans, R.C., Oh, S., Smedmark, J.E., Morgan, D.R., Kerr, M., Robertson, K.R., Arsenault, M., Dickinson, T.A. \& Campbell, C.S. (2007) Phylogeny and classification of Rosaceae. Plant Systematics and Evolution, 266, 5-43.

Powell, E.A. \& Kron, K.A. (2002). Hawaiian Blueberries and Their Relatives-A Phylogenetic Analysis of Vaccinium Sections Macropelma, Myrtillus, and Hemimyrtillus (Ericaceae). Systematic Botany, 27, 768-779.

Wallander, E. \& Albert, V.A. (2000). Phylogeny and classification of Oleaceae based on rps16 and trnL-F sequence data. American Journal of Botany, 87, 1827-1841.

Wojciechowski, M.F., Lavin, M., \& Sanderson, M.J. (2004) A phylogeny of legumes (Leguminosae) based on analysis of the plastid matK gene resolves many well-supported subclades within the family. American Journal of Botany, 91, 1846-1862. 
Appendix S3. IspS phylogenetic analysis on Mediterranean species of the genus Populus and Salix sampled for isoprene emission in this study and belonging to different classes of EIVM (Appendix $\mathrm{S} 1$ ), and on outgroups (North-American species) for which IspS accessions are available. Populus euphratica is denoted with *, as this species was sampled in this study but does not belong to the flora of Italy and is characterized by extreme adaptation to aridity and salinity (Ding et al. 2010).

\begin{tabular}{|l|c|l|}
\hline \multicolumn{1}{|c|}{ Species } & GenBank accessions & \multicolumn{1}{c|}{ References } \\
\hline Populus grandidentata & JN173038 & Gray et al. unpublished \\
\hline Populus fremontii & JN173040 & Gray et al. unpublished \\
\hline Populus deltoides & JN173039 & Gray et al. unpublished \\
\hline Populus trichocarpa & EU693027 & Calfapietra et al. (2007) \\
\hline Populus balsamifera & JN173037 & Gray et al. unpublished \\
\hline Populus tremuloides & AY341431 & Sharkey et al. (2005) \\
\hline Pueraria montana & AY316691 & Sharkey et al. (2005) \\
\hline Populus alba & JQ943922 & this study \\
\hline Populus euphratica $\left(^{*}\right)$ & JQ943923 & this study \\
\hline Populus nigra & JQ943924 & this study \\
\hline Populus tremula & JQ943925 & this study \\
\hline Salix apennina & JQ943915 & this study \\
\hline Salix serpyllifolia & JQ943916 & this study \\
\hline Salix alpina & JQ943917 & this study \\
\hline Salix glabra & JQ943918 & this study \\
\hline Salix pentandra & JQ943919 & this study \\
\hline Salix reticulata & JQ943920 & this study \\
\hline Salix viminalis & JQ943921 & this study \\
\hline
\end{tabular}

Calfapietra, C., Wiberley, A.E., Falbel, T.G., Linskey, A.R., Scarascia Mugnozza, G., Karnosky, D.F., Loreto, F. \& Sharkey. T.D. (2007) Isoprene synthase expression and protein levels are reduced under elevated $\mathrm{O} 3$ but not under elevated $\mathrm{CO} 2$ in field-grown aspen trees. Plant Cell and Environment, 30, 654-661.

Ding, M., Hou, P., Shen, X., Wang, M., Deng, S., Sun, J., Xiao, F., Wang, R., Zhou, X., Lu, C., Zhang, D., Zheng, X., Hu, Z. \& Chen, S. (2010) Salt-induced expression of genes related to $\mathrm{Na}(+) / \mathrm{K}(+)$ and ROS homeostasis in leaves of salt-resistant and salt-sensitive poplar species. Plant Molecular Biology, 73, 251-269.

Sharkey, T.D., Yeh, S., Wiberley, A.E., Falbel, T.G., Gong, D. \& Fernandez, D.E. (2005) Evolution of the isoprene biosynthetic pathway in kudzu. Plant Physiology, 137, 700-712. 
Appendix S4. Primers used in amplification and sequencing of IspS. Primers used in initial PCR reactions are highlighted in bold.

\begin{tabular}{|l|l|}
\hline PRIMER & SEQUENCE 5'-3' \\
\hline PaISPS-Fw2 & gtcgtttggagcattgaagca \\
\hline ISPS_Nested1-F & gttcgaacctcaatatagtg \\
\hline ISPS_Nested2-F & gaggcgtgttggtcttgc \\
\hline ISPS_Nested3_F & cggattatatgaaggttctgc \\
\hline ISPS_Nested4_F & gagttggagctatttacaga \\
\hline ISPS_Nested5_F & gataccatgtcaaggaacca \\
\hline ISPS_Nested6_F & gtacagtataaatttcatcag \\
\hline PaISPS-Bw3 & ttatctctcaaagggtagaat \\
\hline ISPS_Nested1_R & acagaattcgcagtttcacc \\
\hline ISPS_Nested2_R & caggtttcgtctatcaaattc \\
\hline ISPS_Nested3_R & ctgaggatgatttccatgca \\
\hline ISPS_Nested4_R & cttaacaaagccctagaatatg \\
\hline ISPS_Nested5_R & gagtctcatcatcctcattc \\
\hline ISPS_Nested6_R & gttggttccttaacaaagccc \\
\hline
\end{tabular}

22

23

24

25

26

27

28

29

30

31

32

33

34

35

36

37

38

39

40

41

42

43

44

45

46

47

48

49

50

51

52

53

54

55

56

57

58

59

60 